\title{
Article \\ Carpal Tunnel Syndrome: A National Survey to Monitor Knowledge and Operating Methods
}

\author{
Valentina Scalise $^{1}\left(\mathbb{D}\right.$, Fabrizio Brindisino ${ }^{1,2} \mathbb{D}$, Leonardo Pellicciari ${ }^{3, *}$, Silvia Minnucci $^{1}$ and Francesca Bonetti $^{1}$ \\ 1 Department of Clinical Sciences and Translational Medicine, University of Rome Tor Vergata, \\ I-00133 Rome, Italy; scalise.valentina@me.com (V.S.); fabrindi@gmail.com (F.B.); \\ silviaminnucci8@gmail.com (S.M.); fra.bonetti@me.com (F.B.) \\ 2 Department of Medicine and Health Science "Vincenzo Tiberio", University of Molise, \\ I-86100 Campobasso, Italy \\ 3 Neurorehabilitation Research Laboratory, IRCCS San Raffaele Pisana, I-00166 Rome, Italy \\ * Correspondence: leonardo.pellicciari@gmail.com or leonardo.pellicciari@sanraffaele.it; Tel.: +39-32-8568-2656
}

check for updates

Citation: Scalise, V.; Brindisino, F.; Pellicciari, L.; Minnucci, S.; Bonetti, F. Carpal Tunnel Syndrome: A National Survey to Monitor Knowledge and Operating Methods. Int. J. Environ. Res. Public Health 2021, 18, 1995 https://doi.org/10.3390/ ijerph18041995

Academic Editor: Paul B. Tchounwou Received: 12 January 2021 Accepted: 12 February 2021 Published: 18 February 2021

Publisher's Note: MDPI stays neutral with regard to jurisdictional clai$\mathrm{ms}$ in published maps and institutional affiliations.

Copyright: $(\odot 2021$ by the authors. Licensee MDPI, Basel, Switzerland. This article is an open access article distributed under the terms and conditions of the Creative Commons Attribution (CC BY) license (https:// creativecommons.org/licenses/by/ $4.0 /)$

\begin{abstract}
The aim of this article was to investigate the knowledge, management, and clinical practice of Italian physiotherapists concerning patients with carpal tunnel syndrome (CTS). A national crosssectional survey consisted of 24 questions was administered from December 2019 until February 2020. A Chi-squared independence test was run to study any difference between subgroups of the sample and responses to the questionnaire. Five hundred and eight respondents completed the survey. Most respondents $(n=225 / 508 ; 44.3 \%)$ are under 29 years old, female $(n=256 / 508 ; 50.4 \%)$ and have been working as physiotherapists for less than 5 years $(n=213 / 508 ; 41.9 \%)$. Most of respondents correctly knows about the cause $(n=455 / 508,89.6 \%)$, main signs and symptoms of CTS $(n=415 / 508$, $81.70 \%)$ and administer education, manual therapy, myofascial techniques and therapeutic exercises ( $n=457 / 508,89.88 \%$ ). Three hundred and sixty-four $(71.68 \%)$ respondents were aware of the influence of psychosocial factors on the patient's outcomes. The survey showed greater adherence to evidences by physiotherapists holding a master's degree. The results are mostly comparable with other surveys structured all over the world on the same topic. Italian physiotherapists management of the CTS was not always in line with current evidence. Interventions such as education, manual therapy, therapeutic exercise, nerve and tendon glide techniques are widely used, while the orthotic is only offered by half of the sample.
\end{abstract}

Keywords: carpal tunnel syndrome; Italian survey; physiotherapy; care management; rehabilitation

\section{Introduction}

Carpal Tunnel Syndrome (CTS) is described as the most common compressive neuropathy. The prevalence in the American population, regardless of job type, is $7.8 \%$ [1]. In the general population, the incidence is $23 \%$ when the diagnosis is made with clinical and electrodiagnostic criteria, and yet the incidence is higher in the working population than in the general population [2]. In Italy, CTS is the most frequent of the pathologies affecting those who perform manual work, with a substantial increase from 2006 to 2010 (from 1731 to 4819 ) or an increase of over $170 \%$ [3].

The complaints of occupational disease registered by INAIL-National Institute of Accident Insurance-in the first five months of 2019 were 27,385,372 more than in the same period of $2018(+1.4 \%)$. Among these the pathologies of the osteo-muscular system and of the connective tissue (15,556 cases) and of the nervous system (2741, with a superiority of the CTS) continue to represent the first professional diseases reported [4]. CTS determines direct and indirect costs for the entire socio-health system, but in particular when the ability to work is compromised $[2,5,6]$. The risk factors related to CTS are frequently identified in obesity, age, and female sex [7-9]. Weaker correlations are also reported between CTS and high psychological demands in the workplace associated with low decision-making 
authority, vibration, prolonged postures outside the neutral position of the wrist, and repetitive work $[10,11]$. Conversely, the use of computers is not related to an increased risk of developing CTS in the general population [12-20].

Clinically, CTS is characterized by multiple alterations, both motor and sensory [21]: nocturnal paraesthesia, numbness, tingling, decreased sensitivity and pain in the territory innervated by the median nerve, decreased grip strength, and atrophy of the thenar eminence [22]. Recent evidence defines CTS as a complex pain syndrome characterized by the presence of clinical, physical, neurophysiological, and psychological factors involving peripheral and central sensitization processes [23-26].

In most cases, the diagnosis of CTS occurs through anamnesis and clinical examination that makes use of the administration of various provocative tests such as the wrist flexion test (Phalen Test), the nerve percussion test (Tinel sign), the Carpal Compression Test, the Two Point Discrimination Test, and the Semmes-Weinstein Monofilament Test (SWMT) [27-33].

CTS is managed both conservatively and surgically [34]. The conservative treatment of CTS, like all neuro-musculoskeletal pathologies, is the responsibility of the physiotherapist (PT) [35]. With the aim of resolving the symptoms by reducing the course of this disorder, it is very important that the PT is updated according to the most recent and methodologically robust evidence of efficacy in the literature and puts in place such practices to direct own work and propose to the patient the best, most appropriate, and efficient and effective treatment.

In this regard, it is important for the PT to know which activities and occupations increase the risk and the perpetuation of the disease [18], the best specific tests for evaluation [29,33], the most effective treatments, and when medical consultation is essential [36]. While for other pathologies numerous surveys have been conducted on clinical practice in order to determine if and how it is influenced by the evidences present in the literature [37-40], for CTS in Italy have been investigated only the management and treatment following decompression of the nerve by sectioning the transverse carpus ligament [41].

No previous study has ever investigated the current practice of Italian PTs regarding the evaluation and treatment of patients with CTS. Thus, the purpose of this survey is to investigate the knowledge, management, and clinical practice of Italian PTs concerning patients with CTS in order to determine if and how the aforementioned practice is affected by current evidence of efficacy and compare it with the practice of others countries. The secondary objective is to generate inferences between the answers of the survey participants (a) the level of education, (b) the place where the professional activity takes place, and (c) the direct experience in the field calculated as the number of patients with CTS/year.

The authors of this study hypothesize a priori that PTs with a university Master's degree, who carry out their activities in structures specialized in hand rehabilitation and who annually manage multiple cases of CTS, can answer the questions more correctly and are therefore more adherent to current evidence of efficacy.

\section{Materials and Methods}

\subsection{Study Design}

A national cross-sectional survey was carried out on the web for which the guidelines of the Strengthening the Reporting of OBservational Studies in Epidemiology (STROBE) [42] and the Checklist for Reporting Results of Internet E-Surveys (CHERRIES) were used for the construction of the Survey $[42,43]$. The survey was approved by the ethics committee of Lecce, Italy, with Minutes No. 40 of 10 December 2019.

\subsection{Participants and Settings}

The inclusion criterion for completing the questionnaire was to be PTs practicing on Italian territory at the time of completing the survey. Surveys with unanswered were excluded.

Potential participants were reached through a convenience sample with different ways: dissemination of the survey compilation link through social networks (Facebook, Linkedin, Twitter, Instagram), professional sharing platforms (ResearchGate), messaging services 
(WhatsApp, Messenger, Telegram), and e-mail. Two reminders to solicit the completion of the survey were produced and were sent by the Manual Therapy and Musculoskeletal Rehabilitation Group-GTM and by the National Association of Physiotherapists-AIFI to all its members.

In the current survey, the authors' approach was to get the maximum number of responses in a defined period of time. This approach reflects other similar surveys currently present in the literature and conducted in Italy and Europe [44-46]. The time required for completing the questionnaire is 10 to $15 \mathrm{~min}$. This timeframe is chosen for optimizing the response rate in the online questionnaires [47]. It was specified to possible respondents in the initial instructions. To prevent a single respondent from completing the questionnaire multiple times, the server was set up to prevent the same IP address from accessing the survey compilation more than once.

\subsection{Development of the Questionnaire}

The online cross-sectional survey was developed by the authors after a careful analysis of the most recent and methodologically robust literature concerning (a) general knowledge of the pathology of CTS, (b) diagnostic tools, (c) therapeutic techniques, and (d) outcome measures.

After the evaluation of the studies in the literature by four authors (VS, FBo, FB, SM), independently of each other, a provisional version was produced in agreement between the authors themselves. To increase the face validity of this version, the questionnaire was subjected to 10 clinicians of various experience who, blinded to each other, highlighted changes to be made to increase the clarity of the content of the questions, the thesaurus, the order of questions and answers, and the entire survey structure. The authors modified the questionnaire in this sense and proposed this version to the 10 clinicians in the plenary to judge their satisfaction with the changes. When full agreement was reached, the final version of the questionnaire was produced which was used for administration in this survey.

This final version consists of 24 questions in total. In the first part of the questionnaire 8 multiple choice questions were asked with four choices (questions 1-8 in Appendix A) regarding demographic information (e.g., age, region of origin, place of work, etc.). The goal of these questions was to better characterize the background of the professionals who had access to the survey. The subsequent 16 questions (questions 9-24 in Appendix A) were constructed to probe the knowledge of the pathology in question and are multiple choice questions with four possible answers, one of which is correct. The entire survey is available in the Appendix A. The option to decline to answer specific questions or to leave the entire questionnaire blank was also provided [48]. Participants were able to review or change effects using a back button until the end of the questionnaire.

\subsection{Data Collection}

The Survey Monkey online platform (Palo Alto, CA, USA; www.surveymonkey.com, accessed on 10 January 2021) was used. This survey was administered from December 2019 until February 2020 inclusive. This time frame is judged by the authors to be adequate because it is used in other surveys present in the literature [44,45,49]; moreover, after that date no request to fill in the questionnaire was received.

On the first access page to the survey, the purpose of the study and the promoters were specified. It was also specified that the answers would be anonymous and the informed consent was implicit through the will to fill in the survey, detected by the answer "OK" to the phrase "Do you want to proceed to participate in the survey?" (without the need for a written consent form). Participation in the same survey was voluntary and no incentives were given to increase the compilation rate.

For the data analysis, the answers were downloaded and reported in an Excel file with the data extraction method of Survey Monkey from the statistician [22] who was the 
only one to see, sort, and analyze the data -without the IP address- to maintain privacy of respondents [43].

\subsection{Data Analysis}

Descriptive statistics were computed in order to describe the characteristics of the sample. More specifically, mean \pm standard deviation (SD) and frequency with relative percentage were calculated for intervallic and categorical variables, respectively.

In order to study any difference between subgroups of the sample (according to their academic degrees, workplaces, number of patients with CTS/year) and their response to the questionnaire, a Chi-squared independence test or Fisher's exact test (if cell size were below 5) was run. In case the Chi-squared test revealed statistically significant differences $(p<0.05)$, adjusted standardized residuals [50] with their Bonferroni-corrected $p$-value were calculated to determinate which cells of contingency table contributed most to the significant effect [51,52]. The $\alpha$ level was set at $p$-value $<0.05$ for all comparisons, and all statistical analyses were run with SPSS software (SPSS. Version 20 for Windows; Release 13.0.1. SPSS Inc., Chicago, IL, USA, 2004).

\section{Results}

\subsection{Subjects}

A total of 508 participants completed the survey. Most respondents $(n=225 / 508$; $44.3 \%)$ are under 29 years old and female $(n=256 / 508 ; 50.4 \%)$ and have been working as PTs for less than 5 years $(n=213 / 508 ; 41.9 \%)$. Furthermore, most of the respondents only have a Bachelor's degree in physiotherapy $(279 / 508 ; 54.9 \%)$, work in hospitals $(411 / 508$; $80.9 \%)$, and come mainly from Northern Italy $(246 / 508 ; 48.4 \%)$. The main field of work of the respondents involved in this study is the musculoskeletal sector $(389 / 508 ; 76.6 \%)$. 334 respondents $(65.7 \%)$ see 1 to 5 cases of carpal tunnel problems in one year; 106 respondents $(20.9 \%)$ see 6 to 10 patients with carpal tunnel problems every year; 35 respondents (6.9\%) see 11 to 15 cases; and, 30 respondents (5.9\%) visit more than 15 patients with problems related to the CTS per year. Further and detailed information on the personal data of the sample included in this study can be consulted in Table 1.

Table 1. Demographic characteristics of respondents.

\begin{tabular}{|c|c|c|c|c|}
\hline & & Answers $(n)$ & Percentage $(\%)$ & Missing $(n)$ \\
\hline \multirow{4}{*}{ Q 1-Age } & $<29$ & 231 & 44.85 & \multirow{4}{*}{0} \\
\hline & $30-39$ & 167 & 32.43 & \\
\hline & $40-49$ & 66 & 12.82 & \\
\hline & $\geq 50$ & 51 & 9.90 & \\
\hline \multirow{2}{*}{ Q 2-Gender } & Female & 260 & 50.49 & \multirow{2}{*}{0} \\
\hline & Male & 255 & 49.51 & \\
\hline \multirow{4}{*}{ Q 3-Years of experience } & $<5$ years & 219 & 42.52 & \multirow{4}{*}{0} \\
\hline & $5-10$ years & 110 & 21.36 & \\
\hline & $11-20$ years & 123 & 23.88 & \\
\hline & $>20$ years & 63 & 12.23 & \\
\hline \multirow{4}{*}{ Q 4-University degree } & Three-year degree & 279 & 54.28 & \multirow{4}{*}{1} \\
\hline & University Master & 169 & 32.88 & \\
\hline & Master's degree & 56 & 10.89 & \\
\hline & Doctorate & 3 & 0.58 & \\
\hline \multirow{5}{*}{ Q 5-Where do you do business } & Public body (hospital) & 72 & 14.01 & \multirow{5}{*}{1} \\
\hline & Private body & 412 & 80.16 & \\
\hline & Wrist/hand specialized body & 15 & 2.92 & \\
\hline & Society & 8 & 1.56 & \\
\hline & University & 7 & 1.36 & \\
\hline
\end{tabular}


Table 1. Cont.

\begin{tabular}{|c|c|c|c|c|}
\hline & & Answers $(n)$ & Percentage (\%) & Missing (n) \\
\hline \multirow{4}{*}{ Q 6-Business area } & Skeletal muscle & 391 & 76.22 & \multirow{4}{*}{2} \\
\hline & Geriatric & 49 & 9.55 & \\
\hline & Neurological & 59 & 11.50 & \\
\hline & Other & 14 & 2.73 & \\
\hline \multirow{3}{*}{ Q 7-Region of origin } & Northern Italy & 247 & 47.96 & \multirow{3}{*}{0} \\
\hline & Southern Italy & 115 & 22.33 & \\
\hline & Center of Italy & 153 & 29.71 & \\
\hline \multirow{4}{*}{ Q 8-Number of cases per year } & $1-5$ & 341 & 66.60 & \multirow{4}{*}{3} \\
\hline & $6-10$ & 106 & 20.70 & \\
\hline & $11-15$ & 35 & 6.84 & \\
\hline & $>15$ & 30 & 5.86 & \\
\hline
\end{tabular}

Acronyms: Q, question.

\subsection{Primary Outcome}

Question 09: $92.3 \%$ of the participants (469/508) answered correctly stating that CTS is a neurological condition caused by compression of the median nerve due to an increase in pressure in the carpal canal $[17,53]$. In contrast, $7.7 \%(39 / 508)$ claimed that CTS is caused by compression of the ulnar nerve, affects the flexor muscle tendons due to functional overload or affects Guyon's canal.

Question 10: $89.6 \%$ of the participants $(455 / 508)$ correctly answered that the most likely cause of CTS is the reduction of space in the carpal canal $[17,53]$. A small percentage, on the other hand, replied that the most probable causes were a compression of the Guyon canal, an alteration of the collagen and a scaphoid osteophyte $(10.2 \%, 52 / 508)$. One respondent did not answer the question $(1 / 508,0.2 \%)$.

Question 11: For 70.9\% (360/508) of respondents, CTS patients are the responsibility of the PT $[35,54-56] ; 0.8 \%(4 / 508)$ replied that the patient with CTS is not the responsibility of the PT, while $28.3 \%(144 / 508)$ replied that CTS is the responsibility of the PT only after electromyography or a specialist medical examination.

Question 12: 88.2\% (448/508) of participants answered correctly, arguing that the most common risk factors for developing CTS are female gender, obesity, diabetes, and pregnancy $[8,17,53] .11 .6 \%(59 / 508)$ replied that age, male gender, alcohol, smoking, and hormonal diseases are the main risk factors for the development of CTS. One participant $(0.2 \%)$ did not answer the question.

Question 13: $58.7 \%(298 / 508)$ of respondents answered that there is a correlation between computer use and CTS [57,58]. $17.5 \%$ of respondents $(89 / 508)$ answered correctly that there is no correlation between computer use and CTS, $16.3 \%(83 / 508)$ argue that the correlation exists, but only if computer use it is prolonged for more than $10 \mathrm{~h}$ a day, while $7.3 \%(37 / 508)$ of the respondents support the correlation, but only if the use of the computer is accompanied by the use of a non-ergonomic mouse. One participant did not answer the question $(1 / 508,0.2 \%)$.

Question 14: $81.7 \%$ of participants (415/508) answered correctly, claiming that CTS is characterized by impaired sensitivity, tingling, and numbness in the first three fingers of the hand $[59,60] .15 .7 \%(80 / 508)$ argued that impaired sensation, tingling, and numbness of the first three fingers characterize CTS, while 2.6\% (13/508) argued that joint limitation of the radio-carpica or hypothenary muscle strength deficit may characterize CTS.

Question 15: 74.8\% (380/508) of the participants answered correctly, indicating the "hypotrophy of the thenar eminence" [60]. 15.9\% (81/508) of the respondents indicated "dorsal and volar hypotrophy of the hand and hypotrophy of the thenar and hypothenar eminences, $6.1 \%$ (31/508) indicated "hypotrophy of the hypothenar eminence" and $2.8 \%$ $(14 / 508)$ indicated "localized edema in the distal joints". Two respondents $(0.4 \%)$ did not answer the question. 
Question 16: $52.0 \%(264 / 508)$ of the participants replied that the use of SemmesWeinstein Monofilaments is indicated [27,54,59,61]. 17.7\% (90/508) replied that the use of a pin is recommended, $15.0 \%(76 / 508)$ believed that there was no appropriate tool for assessing sensitivity, while $14.4 \%$ (73/508) argued that the description of the symptoms by the patient is sufficient.

Question 17: 67.1\% (341/508) of participants answered correctly, supporting the use of the Wrist Flexion Test (Phalen), the Nerve Percussion Test (Tinel), the Functional Dexterity test and the two points discrimination test [27,54,59,61]. 17.9\% (91/508) of respondents support the choice of the cluster formed by the Phalen Test, Upper Limb Neurodynamic Test 1 (ULNT-1) and stability test of the scaphoid compared to the other carpal bones (Watson's Test), 6.9\% (35/508) supports the choice of the cluster formed by the Cozen's test, a sensitive evaluation test in the thenar area and in the palm of the hand, while $6.5 \%$ (33/508) supports the use of the cluster formed by the Phalen Test, Upper Limb Neurodynamic Test 3 (ULNT-3 for the ulnar nerve), two points discrimination test. $1.6 \%$ $(8 / 508)$ of respondents did not answer this question.

Question 18: 83.3\% (423/508) of respondents respond as recommended by the literature $[54,61]$ indicating "evaluation of sensitivity, dexterity, strength, pain together with a questionnaire for the evaluation of symptoms and functionality". 9.8\% (50/508) responded by supporting the use of "Administration of Visual Analogue Scale (VAS) or the Numeric Pain Rating Scale (NPRS)" together with measuring force with dynamometer and manual dexterity: $6.3 \%(32 / 508)$ of the respondents argues that there is only a need for an interview with the patient. Finally, $0.6 \%(3 / 508)$ of the respondents did not answer the question.

Question 19: 53.0\% (269/508) of respondents answered correctly, claiming that they would recommend or make an orthotic for the management of patients with CTS [54]. $44.3 \%(225 / 508)$ would not recommend it, or would do it only in the case of concomitant rhizo-arthrosis; finally, $2.4 \%(12 / 508)$ argue that the use of the orthotic is contraindicated in patients with CTS. $0.4 \%$ of respondents $(2 / 508)$ did not answer the question.

Question 20: $56.1 \%$ of respondents (285/508) answered that they do not use instrumental therapies in their clinical practice because these methods are supported by weak or moderate evidence of efficacy [54]. 38.2 (194/508) replied that the evidence of efficacy in support of physical therapies in the treatment of the patient with CTS is weak or moderate, but still uses these methods in clinical practice. $4.7 \%$ of respondents $(24 / 508)$ argue that evidence of efficacy in support of physical therapies is strong: 3.7\% (19/508) use them in their clinical practice, while $1 \%(5 / 508)$ of respondents however does not use them. $1 \%$ $(5 / 508)$ of respondents did not answer the question.

Question 21: 49.4\% of respondents (251/508) answered correctly, arguing that the evidence of efficacy in support of nerve and tendon glide techniques is limited/moderate [62,63], but they still use these techniques in their own clinical practice. $34.4 \%(175 / 508)$ of respondents responded that the evidence is strong and that they use these techniques in their clinical practice; $7.5 \%(38 / 508)$ of the respondents replied that the evidence is limited/moderate and for this reason I do not use these techniques while $6.9 \%(35 / 508)$ of the respondents stated that even if based on strong evidence of efficacy, these techniques do not are used in their own clinical practice. Finally, 1.8\% (9/508) of the respondents did not answer the question. The percentage values of use of the main intervention strategies are presented in Figure 1. 


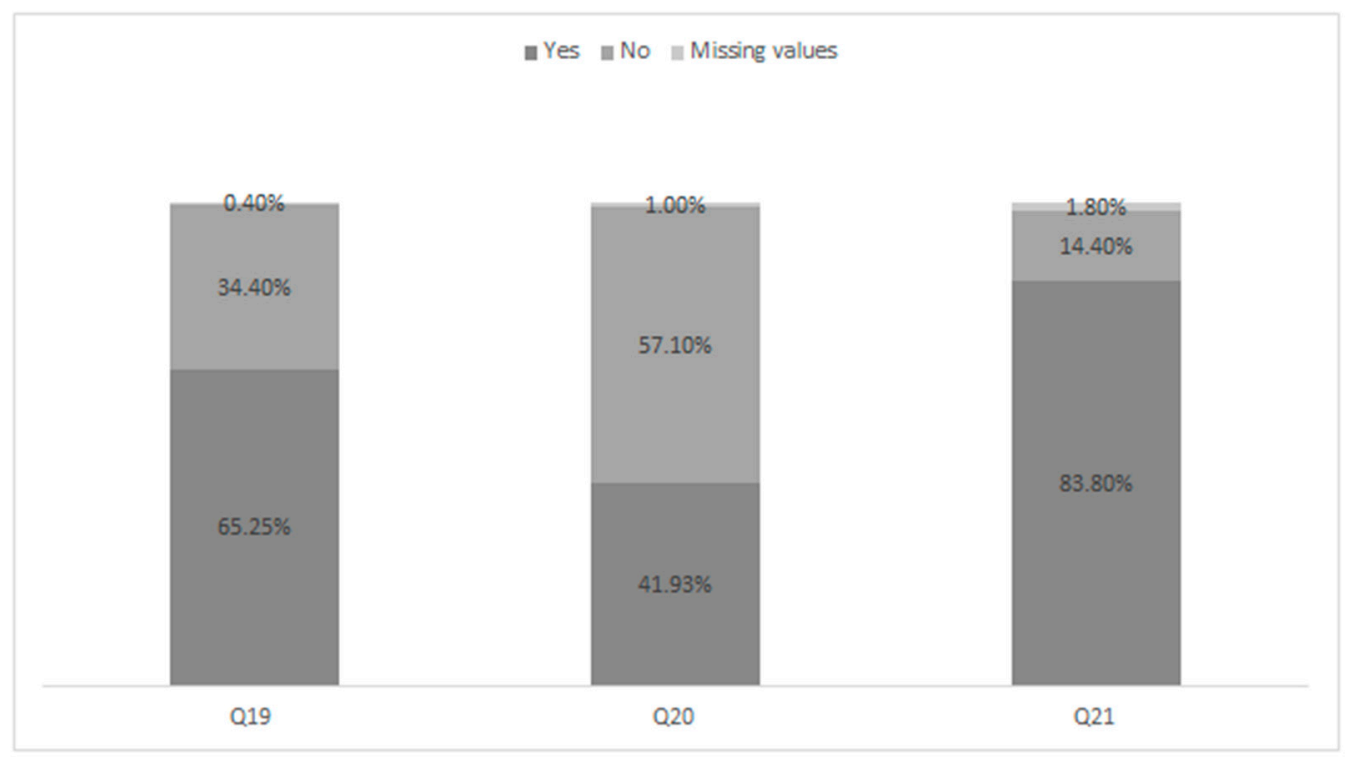

Figure 1. Clinical management for orthotics, instrumental therapies and neuro/tendons glides techniques. Tabled as percentage of respondent $(n=508)$. Q: question. Q19: Orthotic; Q20: Instrumental Therapies; Q21: Neurodynamic/tendons glides techniques.

Question 22: 90\% of respondents (457/508) answered correctly by choosing "education, manual therapy, myofascial therapy and therapeutic exercise" [54,64,65], while $9.8 \%$ $(50 / 508)$ of the respondents used massotherapy, physical therapy, joint mobilization of the radius and stretching. $0.2 \%(1 / 508)$ did not answer the question (Figure 2$)$.

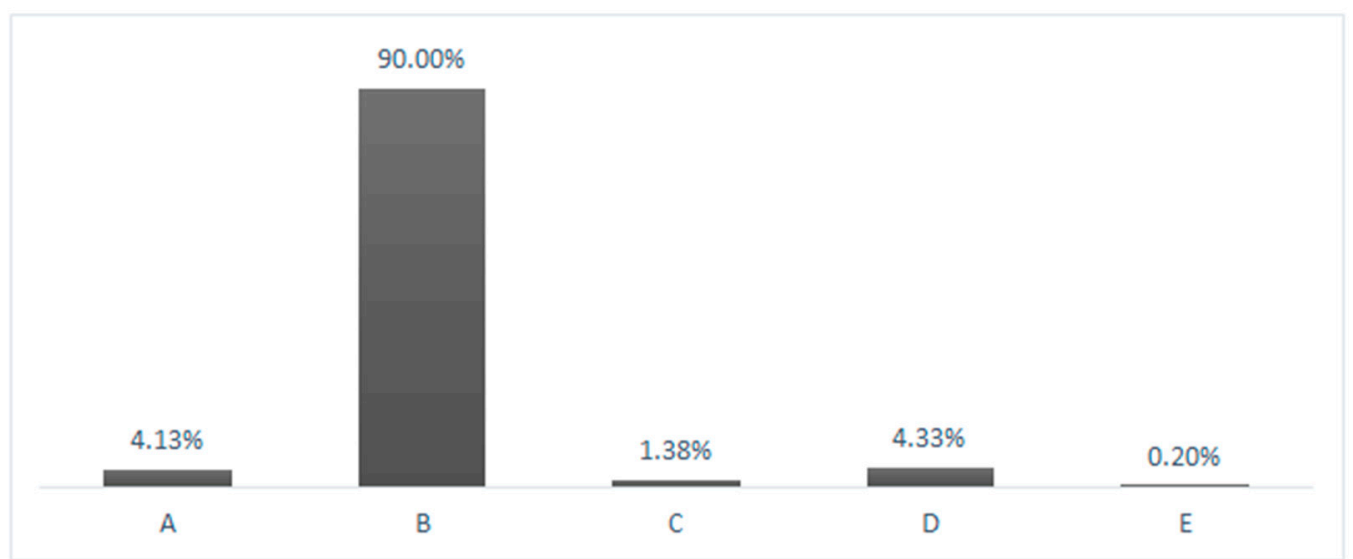

Figure 2. Most frequent treatment strategy for carpal tunnel syndrome. A: Massage therapy, instrumental therapy; B: Education, manual therapy, myofascial therapy, therapeutic exercise; C: Joint mobilization of the radiocarpal joint, stretching; D: None of the previous answers; E: Missing values.

Question 23: 71.7\% of respondents (364/508) answered correctly by choosing "Yes and I adapt my clinical practice accordingly" [24,25,66,67], while $23.4 \%(119 / 508)$ of the respondents maintain that psychosocial factors can influence the patient's outcomes but do not know how to adapt their clinical practice and limit themselves to treating the aspects of education and explanation of the central sensitization processes. $4.5 \%(23 / 508)$ of the respondents instead argued that psychosocial factors do not influence the outcomes of patients with CTS. $0.4 \%(2 / 508)$ did not answer the question.

Question 24: $92.1 \%$ of respondents (468/508) answered correctly, arguing that the surgical approach should be contemplated in case of failure of conservative treatment [36,54], while 
$7.7 \%(39 / 508)$ believe that the surgical approach should not be contemplated or only in concomitant stenosing synovitis. $0.2 \%(1 / 508)$ did not answer the question.

The detailed answers for each question, provided by survey respondents, are described in Appendix B.

\subsection{Secondary Outcome}

The results investigating these topics are summarized in Tables $2-4$.

Table 2. Inferences between correct answers and the respondents' educational qualifications.

\begin{tabular}{|c|c|c|c|c|}
\hline \multirow[b]{2}{*}{ Correct Answer per Question } & \multicolumn{4}{|c|}{ Educational Qualifications } \\
\hline & Bachelor's Degree & University Master & $\begin{array}{l}\text { Master's Degree } \\
\text { or Doctorate }\end{array}$ & $p$ Values \\
\hline $\begin{array}{l}\text { Q9-CTS is a neurological condition caused by } \\
\text { compression of the median nerve due to an } \\
\text { increase in pressure within the carpal tunnel }\end{array}$ & $88.5 \%(247 / 508)$ & $98.2 \%(166 / 508)$ & $93.2 \%(55 / 508)$ & \multirow{3}{*}{$0.001 *$} \\
\hline Adjusted residuals & 3.50 & 3.50 & 0.30 & \\
\hline Residual's $p$-values $($ Bonferroni $p$-values $=0.008)$ & 0.0004 & 0.0004 & 0.7641 & \\
\hline $\begin{array}{l}\text { Q10-CTS is caused by reduction of space within } \\
\text { the carpal canal }\end{array}$ & $87.1 \%(242 / 508)$ & $93.5 \%(158 / 508)$ & $91.5 \%(54 / 508)$ & 0.084 \\
\hline $\begin{array}{c}\text { Q11-Patients with CTS are responsibility of } \\
\text { the physiotherapist }\end{array}$ & $63.0 \%(175 / 508)$ & $80.5 \%(136 / 508)$ & $81.4 \%(48 / 508)$ & \multirow{3}{*}{0.001 * } \\
\hline Adjusted residuals & 4.43 & 3.38 & 1.90 & \\
\hline Residual's $p$-values $($ Bonferroni $p$-values $=0.0055)$ & 0.0000 & 0.0007 & 0.0574 & \\
\hline $\begin{array}{l}\text { Q12-Female gender, obesity, diabetes and } \\
\text { pregnancy are risk factors for CTS }\end{array}$ & $85.3 \%(238 / 508)$ & $94.6 \%(159 / 508)$ & $86.4 \%(51 / 508)$ & $0.010 *$ \\
\hline Adjusted residuals & 2.53 & 3.04 & 0.54 & \\
\hline Residual's $p$-values (Bonferroni $p$-values $=0.0083$ ) & 0.0114 & 0.0023 & 0.58919 & \\
\hline $\begin{array}{c}\text { Q13-There's no association between CTS } \\
\text { and computer }\end{array}$ & $61.9 \%(172 / 508)$ & $52.1 \%(88 / 508)$ & $62.7 \%(37 / 508)$ & 0.088 \\
\hline $\begin{array}{l}\text { Q14-Altered sensitivity, tingling and numbness } \\
\text { of the first three fingers are the main characters } \\
\text { of CTS }\end{array}$ & $80.3 \%(224 / 508)$ & $83.4 \%(141 / 508)$ & $83.1 \%(49 / 508)$ & 0.843 \\
\hline $\begin{array}{l}\text { Q15-In patients with CTS is possible to find } \\
\text { hypotrophy of the thenar eminence }\end{array}$ & $71.2 \%(198 / 508)$ & $81.0 \%(136 / 508)$ & $78 \%(46 / 508)$ & 0.150 \\
\hline $\begin{array}{l}\text { Q16-The Semmes-Weinstein Monofilaments are } \\
\text { the best tool for the tactile sensitivity examination }\end{array}$ & $35.3 \%(97 / 508)$ & $77.4 \%(130 / 508)$ & $61 \%(36 / 508)$ & \multirow{3}{*}{$0.000 *$} \\
\hline Adjusted residuals & 8.47 & 7.95 & 1.41 & \\
\hline Residual's $p$-values (Bonferroni $p$-values $=0.0041$ ) & 0.0000 & 0.0000 & 0.15853 & \\
\hline $\begin{array}{c}\text { Q17-Wrist flexion test (Phalen's test), nerve } \\
\text { percussion test (Tinel's sign), Functional } \\
\text { Dexterity test and two-point discrimination are } \\
\text { most used clinical test }\end{array}$ & $66.3 \%(181 / 508)$ & $71.4 \%(120 / 508)$ & $67.2 \%(39 / 508)$ & 0.068 \\
\hline $\begin{array}{c}\text { Q18-Measurement of strength with } \\
\text { dynamometer and of sensitivity, manual } \\
\text { dexterity, strength and pain and administration } \\
\text { of a questionnaire for the evaluation of symptoms } \\
\text { and function are the most used outcome } \\
\text { evaluation tools }\end{array}$ & $79.4 \%(220 / 508)$ & $89.9 \%(151 / 508)$ & $88.1 \%(52 / 508)$ & \multirow[t]{3}{*}{0.010 * } \\
\hline Adjusted residuals & 3.04 & 2.57 & 0.94 & \\
\hline Residual's $p$-values (Bonferroni $p$-values $=0.0055)$ & 0.00236 & 0.01016 & 0.34721 & \\
\hline Q19-I advice or build an orthotic & $50.9 \%(142 / 508)$ & $57.5 \%(96 / 508)$ & $50.8 \%(30 / 508)$ & 0.073 \\
\hline $\begin{array}{l}\text { Q20-I don't use instrumental therapies in my } \\
\text { clinical practice; supporting evidences are } \\
\text { weak/moderate }\end{array}$ & $52.6 \%(144 / 508)$ & $61.5 \%(104 / 508)$ & $61 \%(36 / 508)$ & 0.145 \\
\hline $\begin{array}{l}\text { Q21-There is limited evidence on neural and } \\
\text { tendon glide techniques and that's why I don't } \\
\text { use it in my clinical practice }\end{array}$ & $47.1 \%(128 / 508)$ & $52.7 \%(88 / 508)$ & $57.6 \%(34 / 508)$ & 0.152 \\
\hline
\end{tabular}


Table 2. Cont.

\begin{tabular}{|c|c|c|c|c|}
\hline \multirow[b]{2}{*}{ Correct Answer per Question } & \multicolumn{4}{|c|}{ Educational Qualifications } \\
\hline & Bachelor's Degree & University Master & $\begin{array}{l}\text { Master's Degree } \\
\text { or Doctorate }\end{array}$ & $p$ Values \\
\hline $\begin{array}{l}\text { Q22-Education, manual therapy, myofascial } \\
\text { therapy, therapeutic exercise are most used } \\
\text { treatment strategies }\end{array}$ & $86.3 \%(240 / 508)$ & $95.3 \%(161 / 508)$ & $93.2 \%(55 / 508)$ & $0.006 *$ \\
\hline Adjusted residuals & 3.15 & 2.75 & 0.85 & \\
\hline Residual's $p$-values (Bonferroni $p$-values $=0.0083$ ) & 0.00163 & 0.00595 & 0.39532 & \\
\hline $\begin{array}{l}\text { Q23-I adapt my clinical practice accordingly } \\
\text { with the influence of psychosocial factors on the } \\
\text { patient outcome }\end{array}$ & $64.6 \%(179 / 508)$ & $80.5 \%(136 / 508)$ & $81.4 \%(48 / 508)$ & 0002 * \\
\hline Adjusted residuals & 4.00 & 3.05 & 2.63 & \\
\hline Residual's $p$-values (Bonferroni $p$-values $=0.0055$ ) & 0.00006 & 0.00228 & 0.08543 & \\
\hline $\begin{array}{l}\text { Q24-the surgical approach can be a solution in } \\
\text { cases of failure of conservative treatment } \\
\text { (persistence of symptoms) }\end{array}$ & $90.6 \%(252 / 508)$ & $96.4 \%(163 / 508)$ & $88.1 \%(52 / 508)$ & $0.037^{*}$ \\
\hline Adjusted residuals & 1.53 & 2.48 & 1.27 & \\
\hline $\begin{array}{l}\text { Residual's } p \text {-values (Bonferroni } \\
p \text {-values }=0.00833 \text { ) }\end{array}$ & 0.12601 & 0.01313 & 0.20408 & \\
\hline
\end{tabular}

Acronyms: CTS, Carpal Tunnel Syndrome; n.s., not-significant; Q, question. NOTE: * ${ }^{*}$ Significant $p$-values $(p<0.05)$; statistically significant differences according to the corrected residuals are in bold.

Table 3. Inferences between correct answers and place of professional activity of the respondents.

\begin{tabular}{|c|c|c|c|c|c|c|}
\hline \multirow[b]{2}{*}{ Correct Answer per Question } & \multicolumn{6}{|c|}{ Place of Professional Activity } \\
\hline & Hospital & Private Practice & $\begin{array}{l}\text { Rehabilitation } \\
\text { Clinic }\end{array}$ & Sport Society & University & $p$ Value \\
\hline $\begin{array}{l}\text { Q9-CTS is a neurological } \\
\text { condition caused by } \\
\text { compression of the median } \\
\text { nerve due to an increase in } \\
\text { pressure within the } \\
\text { carpal tunnel }\end{array}$ & $93.4 \%(384 / 508)$ & $87.1 \%(61 / 50)$ & $100 \%(15 / 508)$ & $71.4 \%(5 / 508)$ & $100 \%(4 / 508)$ & 0.051 \\
\hline $\begin{array}{l}\text { Q10-CTS is caused by } \\
\text { reduction of space within the } \\
\text { carpal canal }\end{array}$ & $91.0 \%(373 / 508)$ & $81.4 \%(57 / 50)$ & $100 \%(15 / 508)$ & $85.7 \%(6 / 508)$ & $75.0 \%(3 / 508)$ & 0.069 \\
\hline $\begin{array}{l}\text { Q11-Patients with CTS are } \\
\text { responsibility of the } \\
\text { physiotherapist }\end{array}$ & $71.0 \%(292 / 508)$ & $72.9 \%(51 / 50)$ & $66.7 \%(10 / 508)$ & $57.1 \%(4 / 508)$ & $75.0 \%(3 / 508)$ & 0.983 \\
\hline $\begin{array}{l}\text { Q12-Female gender, obesity, } \\
\text { diabetes and pregnancy are } \\
\text { risk factors for CTS }\end{array}$ & $88.5 \%(363 / 508)$ & $90.0 \%(63 / 50)$ & $100.0 \%(15 / 508)$ & $42.9 \%(3 / 508)$ & $75 \%(3 / 508)$ & \\
\hline Adjusted residuals & 0.28 & 0.47 & 1.43 & 3.78 & 0.83 & $0.002 *$ \\
\hline $\begin{array}{c}\text { Residual's } p \text {-values } \\
\text { (Bonferroni } p \text {-value }=0.005 \text { ) }\end{array}$ & 0.77947 & 0.63835 & 0.15271 & 0.00015 & 0.40653 & \\
\hline $\begin{array}{l}\text { Q13-There's no association } \\
\text { between CTS and computer }\end{array}$ & $57.6 \%(236 / 508)$ & $67.1 \%(47 / 50)$ & $46.7 \%(7 / 508)$ & $57.1 \%(4 / 508)$ & $100 \%(4 / 508)$ & 0.699 \\
\hline $\begin{array}{l}\text { Q14-Altered sensitivity, } \\
\text { tingling and numbness of the } \\
\text { first three fingers are the main } \\
\text { characters of CTS }\end{array}$ & $83.0 \%(341 / 508)$ & $72.9 \%(51 / 50)$ & $86.7 \%(13 / 508)$ & $71.4 \%(5 / 508)$ & $100 \%(4 / 508)$ & 0.462 \\
\hline $\begin{array}{l}\text { Q15-In patients with CTS is } \\
\text { possible to find hypotrophy of } \\
\text { the thenar eminence }\end{array}$ & $76.3 \%(312 / 508)$ & $68.6 \%(48 / 50)$ & $86.7 \%(13 / 508)$ & $42.9 \%(3 / 508)$ & $100 \%(4 / 508)$ & 0.596 \\
\hline
\end{tabular}


Table 3. Cont.

\begin{tabular}{|c|c|c|c|c|c|c|}
\hline \multirow[b]{2}{*}{ Correct Answer per Question } & \multicolumn{6}{|c|}{ Place of Professional Activity } \\
\hline & Hospital & Private Practice & $\begin{array}{l}\text { Rehabilitation } \\
\text { Clinic }\end{array}$ & Sport Society & University & $p$ Value \\
\hline $\begin{array}{l}\text { Q16-The Semmes-Weinstein } \\
\text { Monofilaments are the best } \\
\text { tool for the tactile } \\
\text { sensitivity examination }\end{array}$ & $52.2 \%(212 / 508)$ & $47.1 \%(33 / 50)$ & $86.7 \%(3 / 508)$ & $57.1 \%(4 / 508)$ & $50 \%(2 / 508)$ & 0.252 \\
\hline $\begin{array}{l}\text { Q17-Wrist flexion test } \\
\text { (Phalen's test), nerve } \\
\text { percussion test (Tinel's sign), } \\
\text { Functional Dexterity test and } \\
\text { two-point discrimination are } \\
\text { most used clinical test }\end{array}$ & $67.2 \%(272 / 508)$ & $67.6 \%(46 / 50)$ & $93.3 \%(14 / 508)$ & $71.4 \%(5 / 508)$ & $75 \%(3 / 508)$ & 0.229 \\
\hline $\begin{array}{l}\text { Q18-Measurement of } \\
\text { strength with dynamometer } \\
\text { and of sensitivity, manual } \\
\text { dexterity, strength and pain } \\
\text { and administration of a } \\
\text { questionnaire for the } \\
\text { evaluation of symptoms and } \\
\text { function are the most used } \\
\text { outcome evaluation tools }\end{array}$ & $84.1 \%(345 / 508)$ & $82.4 \%(56 / 50)$ & $86.7 \%(13 / 508)$ & $71.4 \%(5 / 508)$ & $100 \%(4 / 508)$ & 0.836 \\
\hline $\begin{array}{l}\text { Q19-I advice or build } \\
\text { an orthotic }\end{array}$ & $53.2 \%(218 / 508)$ & $50.7 \%(35 / 50)$ & $80.0 \%(12 / 508)$ & $28.6 \%(2 / 508)$ & $25 \%(1 / 508)$ & 0.123 \\
\hline $\begin{array}{l}\text { Q20-I don't use instrumental } \\
\text { therapies in my clinical } \\
\text { practice; supporting evidences } \\
\text { are weak/moderate }\end{array}$ & $58.5 \%(238 / 508)$ & $53.6 \%(37 / 50)$ & $33.3 \%(5 / 508)$ & $42.9 \%(3 / 508)$ & $50 \%(2 / 508)$ & 0.612 \\
\hline $\begin{array}{l}\text { Q21-There is limited } \\
\text { evidence on nerve and tendon } \\
\text { glide techniques and that's } \\
\text { why I don't use it in my } \\
\text { clinical practice }\end{array}$ & $50.2 \%(203 / 508)$ & $50 \%(34 / 50)$ & $53.3 \%(8 / 508)$ & $42.9 \%(3 / 508)$ & $75 \%(3 / 508)$ & 0.900 \\
\hline $\begin{array}{l}\text { Q22-Education, manual } \\
\text { therapy, myofascial therapy, } \\
\text { therapeutic exercise are most } \\
\text { used treatment strategies }\end{array}$ & $90.3 \%(371 / 508)$ & $92.8 \%(64 / 50)$ & $80.0 \%(12 / 508)$ & $100 \%(7 / 508)$ & $75 \%(3 / 508)$ & 0.390 \\
\hline $\begin{array}{l}\text { Q23-I adapt my clinical } \\
\text { practice accordingly with the } \\
\text { influence of psychosocial } \\
\text { factors on the patient outcome }\end{array}$ & $71 \%(291 / 508)$ & $75.4 \%(52 / 50)$ & $73.3 \%(11 / 508)$ & $100 \%(7 / 508)$ & $75 \%(3 / 508)$ & 0.861 \\
\hline $\begin{array}{l}\text { Q24-the surgical approach } \\
\text { can be a solution in cases of } \\
\text { failure of conservative } \\
\text { treatment (persistence } \\
\text { of symptoms) }\end{array}$ & $93.9 \%(385 / 508)$ & $84.3 \%(59 / 50)$ & $93.3 \%(14 / 508)$ & $100 \%(7 / 508)$ & $50 \%(2 / 508)$ & $0.001 *$ \\
\hline Adjusted residuals & 2.81 & 2.71 & 0.15 & 0.77 & 3.18 & \\
\hline $\begin{array}{c}\text { Residual's } p \text {-values } \\
\text { (Bonferroni } p \text {-value }=0.005 \text { ) }\end{array}$ & 0.00495 & 0.00672 & 0.88076 & 0.44129 & 0.00147 & \\
\hline
\end{tabular}

Acronyms: Q, question; CTS, Carpal Tunnel Syndrome; n.s., non-significant. NOTES: ${ }^{*}=$ significant $p$-values $(p<0.05)$, statistically significant differences according to the corrected residuals are in bold. 
Table 4. Inferences between correct answers and number of cases treated each year by respondents.

\begin{tabular}{|c|c|c|c|c|c|}
\hline \multirow[b]{2}{*}{ Correct Answer per Question } & \multicolumn{5}{|c|}{ Number of CTS Patients/Year } \\
\hline & $1-5$ & $6-10$ & 11-15 & $>15$ & $p$ Value \\
\hline $\begin{array}{l}\text { Q9-CTS is a neurological condition caused by } \\
\text { compression of the median nerve due to an } \\
\text { increase in pressure within the carpal tunnel }\end{array}$ & $93.4 \%(312 / 508)$ & $91.5 \%(97 / 508)$ & $80.0 \%(28 / 508)$ & $96.7 \%(29 / 508)$ & 0031 * \\
\hline Adjusted residuals & 1.34 & 0.33 & 2.82 & 0.93 & \\
\hline Residual's $p$-values (Bonferroni $p$-value $=0.0062$ ) & 0.18024 & 0.74139 & 0.00480 & 0.35237 & \\
\hline $\begin{array}{l}\text { Q10-CTS is caused by reduction of space within } \\
\text { the carpal canal }\end{array}$ & $90.4 \%(302 / 508)$ & $87.7 \%(93 / 508)$ & $91.4 \%(32 / 508)$ & $86.2 \%(25 / 508)$ & 0.771 \\
\hline $\begin{array}{l}\text { Q11-Patients with CTS are responsibility of } \\
\text { the physiotherapist }\end{array}$ & $72.2 \%(241 / 508)$ & $70.8 \%(75 / 508)$ & $60.0 \%(21 / 508)$ & $70 \%(21 / 508)$ & 0.784 \\
\hline $\begin{array}{l}\text { Q12-Female gender, obesity, diabetes and } \\
\text { pregnancy are risk factors for CTS }\end{array}$ & $88.6 \%(295 / 508)$ & $84.9 \%(90 / 508)$ & $88.6 \%(31 / 508)$ & $100 \%(30 / 508)$ & 0.155 \\
\hline $\begin{array}{c}\text { Q13-There's no association between CTS } \\
\text { and computer }\end{array}$ & $57.2 \%(191 / 508)$ & $56.2 \%(59 / 508)$ & $68.6 \%(24 / 508)$ & $70 \%(21 / 508)$ & 0.281 \\
\hline $\begin{array}{l}\text { Q14-Altered sensitivity, tingling and numbness } \\
\text { of the first three fingers are the main characters } \\
\text { of CTS }\end{array}$ & $81.7 \%(273 / 508)$ & $83 \%(88 / 508)$ & $77.1 \%(27 / 508)$ & $83.3 \%(25 / 508)$ & 0.239 \\
\hline $\begin{array}{l}\text { Q15-In patients with CTS is possible to find } \\
\text { hypotrophy of the thenar eminence }\end{array}$ & $77.2 \%(257 / 508)$ & $74.3 \%(78 / 508)$ & $57.1 \%(20 / 508)$ & $76.7 \%(23 / 508)$ & 0.308 \\
\hline $\begin{array}{l}\text { Q16-The Semmes-Weinstein Monofilaments are } \\
\text { the best tool for the tactile sensitivity examination }\end{array}$ & $53.3 \%(177 / 508)$ & $51.0 \%(53 / 508)$ & $48.6 \%(17 / 508)$ & $53.3 \%(16 / 508)$ & 0.619 \\
\hline $\begin{array}{c}\text { Q17-Wrist flexion test (Phalen's test), nerve } \\
\text { percussion test (Tinel's sign), Functional Dexterity } \\
\text { test and two-point discrimination are most used } \\
\text { clinical test }\end{array}$ & $64.4 \%(212 / 508)$ & $71.4 \%(75 / 508)$ & $77.1 \%(27 / 508)$ & $89.7 \%(26 / 508)$ & 0.033 * \\
\hline Adjusted residuals & 2.57 & 0.78 & 1.17 & 2.55 & \\
\hline Residual's $p$-values $($ Bonferroni $p$-value $=0.0031$ ) & 0.01016 & 0.43539 & 0.24200 & 0.01077 & \\
\hline $\begin{array}{l}\text { Q18-Measurement of strength with } \\
\text { dynamometer and of sensitivity, manual dexterity, } \\
\text { strength and pain and administration of a } \\
\text { questionnaire for the evaluation of symptoms and } \\
\text { function are the most used outcome } \\
\text { evaluation tools }\end{array}$ & $86.1 \%(285 / 508)$ & $81.1 \%(86 / 508)$ & $68.6 \%(24 / 508)$ & $83.3 \%(25 / 508)$ & 0.120 \\
\hline Q19-I advice or build an orthotic & $55.1 \%(183 / 508)$ & $49.1 \%(52 / 508)$ & $45.7 \%(16 / 508)$ & $60.0 \%(18 / 508)$ & 0.310 \\
\hline $\begin{array}{l}\text { Q20-I don't use instrumental therapies in my } \\
\text { clinical practice; supporting evidences are } \\
\text { weak/moderate }\end{array}$ & $60.6 \%(200 / 508)$ & $52.8 \%(56 / 508)$ & $45.7 \%(16 / 508)$ & $40.0 \%(12 / 508)$ & 0.060 \\
\hline $\begin{array}{l}\text { Q21-There is limited evidence on neural and } \\
\text { tendon glide techniques and that's why I don't use } \\
\text { it in my clinical practice }\end{array}$ & $50.2 \%(165 / 508)$ & $50 \%(52 / 508)$ & $48.6 \%(17 / 508)$ & $53.3 \%(16 / 508)$ & 0.612 \\
\hline $\begin{array}{l}\text { Q22-Education, manual therapy, myofascial } \\
\text { therapy, therapeutic exercise are most used } \\
\text { treatment strategies }\end{array}$ & $92.2 \%(307 / 508)$ & $88.7 \%(94 / 508)$ & $80 \%(28 / 508)$ & $83.3 \%(25 / 508)$ & 0.060 \\
\hline $\begin{array}{c}\text { Q23-I adapt my clinical practice accordingly with } \\
\text { the influence of psychosocial factors on the } \\
\text { patient outcome }\end{array}$ & $71.1 \%(236 / 508)$ & $74.5 \%(79 / 508)$ & $71.4 \%(25 / 508)$ & $70.0 \%(21 / 508)$ & 0.948 \\
\hline $\begin{array}{l}\text { Q24-the surgical approach can be a solution in } \\
\text { cases of failure of conservative treatment } \\
\text { (persistence of symptoms) }\end{array}$ & $90.4 \%(301 / 508)$ & $\begin{array}{c}95.3 \% \\
(101 / 508)\end{array}$ & $97.1 \%(34 / 508)$ & $96.7 \%(29 / 508)$ & 0.174 \\
\hline
\end{tabular}

Acronyms: Q, question; CTS, Carpal Tunnel Syndrome; n.s., non-significant. NOTES: ${ }^{*}=$ significant $p$-values $(p<0.05)$, statistically significant differences according to the corrected residuals are in bold.

For the inference between the correct answer and the respondents' level of education, the answers are summarized in Table 2 and inferences with statistical significance is presented in Figure 3. 


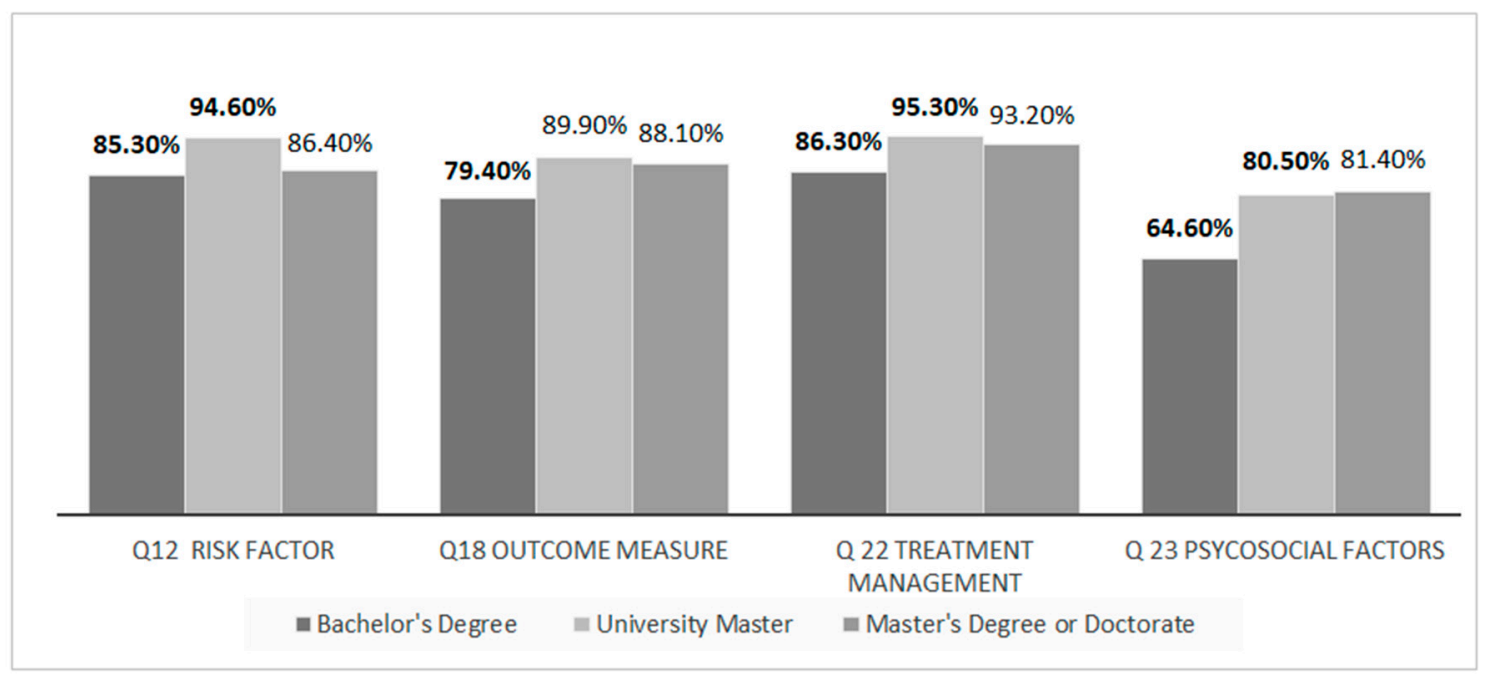

Figure 3. Inferences between educational qualifications and correct answers (Q12, Q18, Q22, Q23). Acronyms: Q: question. Bold values outside the box are the ones with statistical significance in the residual $p$-values. Tabled as percentage of respondent $(n=508)$.

The results of the inferences between the correct answer to each question and the respondents' prevailing workplace are summarized in Table 3 and inference with statistical significance is graphically presented in Figure 4.

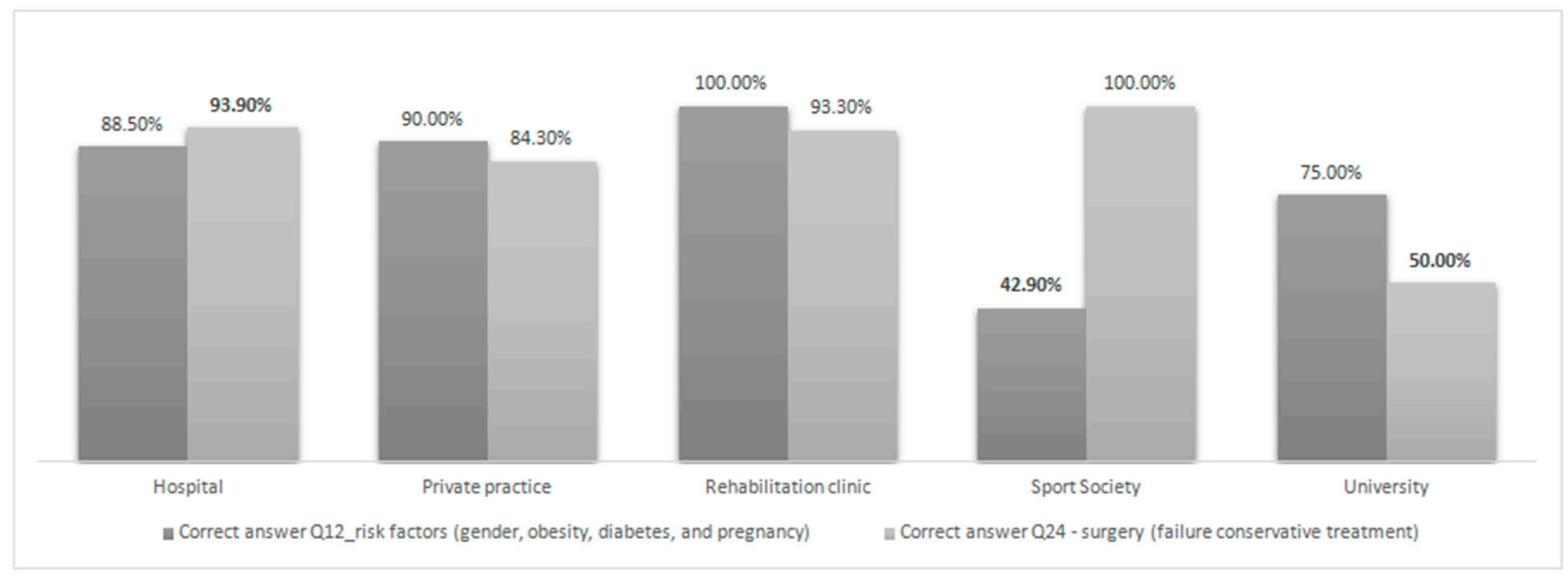

Figure 4. Inferences between places of professional activity and correct answers (Q12 and Q24). Acronyms: Q, question. Bold values outside the box are the ones with statistical significance in the residual $p$-values. Tabled as percentage of respondent $(n=508)$.

\section{Discussion}

The objectives of this study are to provide information on the knowledge and current clinical practice of Italian PTs in relation to CTS, to determine whether this practice is in line with current evidence of efficacy, and to evaluate the inferences between participants ${ }^{\prime}$ responses to the survey and the level of education, workplace, and direct experience in the field (calculated with number of CTS patients/year).

The definition that most respondents in this study believe correct for CTS is in line with the American Academy of Orthopedic Surgeons (AAOS) [53], which describes it as "symptomatic neuropathy from compression of the median nerve at the wrist level, physiologically characterized by the presence of an increase in pressure within the carpal canal and a reduction in nerve function at this level". 
Almost all of the PTs interviewed know the main risk factors reported in the literature for the development of CTS, such as female gender, obesity, diabetes, and pregnancy $[8,17,61]$. A widespread belief among Italian PTs is that CTS is associated with the use of computers, although the evidence available in the literature for this claim is controversial $[14,18]$. Some studies suggest that excessive computer use may be a minor risk factor for the onset of CTS [61], but two recent meta-analyzes have concluded that to date it is not possible to establish a direct causal association with certainty $[57,58]$.

Most Italian PTs seem to be aware of the main nosological features of CTS such as pain, numbness, tingling, paraesthesia, and impaired sensitivity in the distribution area of the median nerve [59]. In addition, more than three quarters of the interviewed sample appear to recognize typical alterations of the most advanced stage such as hypotrophy or atrophy of the thenar eminence, with a reduction in grip strength and manual dexterity and consequent loss of function [60]. This finding is in line with Australian PTs' confidence in recognizing neurological disorders [68].

The evidence currently available in the literature suggests that the physical examination should include a battery of diagnostic tests, as well as specific outcome measures [54]; in fact, no single test alone can be sufficient for a definitive diagnosis of CTS [17]. Provocative tests considered valid for the diagnosis of CTS and commonly used internationally and by more than half of the sample interviewed include Tinel's sign, Phalen's test, Dellonmodified Moberg pick-up test or Purdue Pegboard, the two-points static discrimination test, and the Semmes-Weinstein monofilament test (SWMT) [27,54,59].

The SWMT is a valid test known only by just over half of Italian PTs and is a quantitative and objective method for mapping the loss of sensation within the distribution of the median nerve of patients with moderate to severe CTS [54,69]. Unfortunately, it emerges from this study that most Italian PTs relegate the sensitivity test to instruments that have proved unreliable (e.g., pin) or do not perform it on account of an inability to identify any appropriate instrument.

Outcome measures, known to most of the PTs who participated in the survey, include a pain measurement scale, measurement of global and clamp force through the use of a dynamometer, assessment of manual dexterity, assessment sensitivity, and the administration of validated scales for the evaluation of symptoms and function (e.g., PROMS validated in Italian such as Disabilities of the Arm, Shoulder and Hand questionnaire [DASH] or Boston Carpal Tunnel Syndrome Questionnaire [BCTQ]) [54,61].

With CTS being a musculoskeletal disorder that can be treated conservatively and according to rehabilitative procedures, conservative treatment of CTS is the responsibility of the PT [35]. Additionally, the conservative approach has shown success in many studies in the literature with various follow-ups [54-56]. However, about one third of the respondents to this questionnaire would treat the patient with CTS only after PT has undergone a specialist medical examination or a median nerve conduction study with electromyography (EMG). This result is not perfectly in line with the evidence of efficacy present in the literature, which instead tend to promote a medical-surgical consultation only when patients regress, do not improve with conservative management, or present severe CTS and severe atrophy of the thenar eminence [54]. Electrodiagnostic studies and imaging studies, on the other hand, are generally reserved for patients in whom diagnostic certainty is questionable, but in the case of CTS there is controversy in the literature: although EMG is commonly used, there is limited evidence regarding the its usefulness in diagnosing CTS $[17,53,70]$. In fact, with a sensitivity from $49 \%$ to $84 \%$ and a specificity from $95 \%$ to $99 \%$, it may not be sufficiently reliable, when negative, to exclude the presence of pathology [53]. Recent studies have shown that sonoelastography is a useful non-invasive and promising modality to diagnose CTS [71]. As for the conservative treatment of CTS, the best evidence available in the literature supports the use of a night orthotic with the wrist in a neutral position with the aim of reducing symptoms [54]. Only half of the recruited sample proposes the orthotic as a treatment strategy for CTS. These results are different from those of an American survey, which shows that the orthotic is the most commonly 
used conservative intervention by all PTs who are members of the American Society of Hand [72]. The low use of orthoses in this survey may be related to the fact that PTs are not comfortable with this intervention. Probably, if the sample consisted exclusively of hand therapists the percentage of orthotic use would be higher and therefore the results would be more similar to the American survey [72].

The 2019 JOSPT (Journal of Orthopedic \& Sports Physical Therapy) guideline showed that instrumental therapies such as magnetotherapy, low-level laser therapy, ultrasound, and iontophoresis provide no benefit in the management of CTS [54]. This survey highlights a substantial confusion in the use of instrumental therapy in the clinical practice of Italian PTs who are almost equally divided between those who use it and those who do not. These results are in contrast to the US survey, which shows that instrumental therapies, with the exception of ultrasound, are scarcely used by American PTs [72]. Probably the tendency of Italian PTs to propose mechanically ineffective interventions in clinical practice derives from the fact that, as also highlighted in the study by Giovannico et al. [73], basic academic training programs would need to be modified in order to allow this scientific discipline to reach its maximum potential.

Nerve mobilization techniques and tendon glide exercises appear to be widely used by Italian PTs, despite conflicting and limited evidence of efficacy supporting these interventions $[62,63,74-76]$. The results of the present study are similar to both those of the American survey by Parish et al. [72] and those of the worldwide survey on the clinical practice of PTs and occupational therapists following the Carpal Tunnel Release (CTR) [41].

The 2019 JOSPT guideline suggests that patient education programs, ergonomic interventions, manual therapy of the cervical spine and upper limb, myofascial and therapeutic exercise can be offered to patients with CTS [54], although these interventions are supported by moderate or limited and low quality evidence $[54,64,65]$. The results of this survey reflect current recommendations and are similar to those reported in the US survey [72]. In fact, almost all of the respondents choose to provide such a combination of interventions for the management of the CTS.

Although it has now been shown in the literature that the painful function and experience of patients with CTS can be influenced by psychosocial factors [24-26,66,67,77], there is an unfortunate tendency to overlook these factors in clinical practice. The present survey reflects this problem so much that almost a quarter of the participants, although aware of the importance of psychosocial variables, seem to find it difficult to identify and manage these variables.

Finally, almost all respondents agree that, in case of failure of conservative treatment, the surgical approach can be a solution for patients with CTS [36,54]. This is also confirmed by another survey that identifies the perception of the benefit of surgery by hand therapists, which appears to be similar to that of surgeons [78].

As expected by the authors of this study, some significant differences emerged from the analysis of the results regarding the cultural level of the PTs interviewed: those specialized in holding a University Master's degree seem to be more in line with the current evidence of effectiveness. The results of this study align with those of other Italian surveys [46] and may be justified by the fact that in Italy the Master's Degree Course provides professional training mainly oriented towards the acquisition of skills in management, training, and research processes and not towards the deepening of specialist clinical knowledge.

Contrary to what was expected in the initial hypotheses, however, no differences were highlighted in relation to the place of professional activity or the clinical experience of the Italian PTs. This means that carrying out one's activity in a specialized setting or managing multiple CTS cases annually does not necessarily imply greater knowledge, competence, and adherence to evidence-based clinical practice (EBP), but rather, it is probably the study — and continuous individual study — of the subject that allows the clinician to make decisions based on evidence. 


\section{Strengths and Limitations of the Study}

This study is limited to Italian PTs only and analyzes only a part of the population of clinical PTs: those who usually use social media or electronic devices (even if now almost all healthcare professionals are familiar with technology and the use of smartphones as it has become common practice in the management of health communication) [79]. This may not represent the entire PT population and thus represent a selection bias. This limitation has been identified in other surveys in the musculoskeletal field [38]. In fact, it is recognized that self-administered questionnaires are not useful for studying populations that do not use the technology [80]. Furthermore, the choice of orienting the survey towards a single professional category may not represent the interprofessional idea of the evaluation and treatment of CTS. This is the first survey aimed at analyzing the perception of PTs on the subject.

The strength of this study is in the rigorous statistical analysis, the analysis of the sub-classification of the sample, and the methodological construction of the survey. This survey is also the result of a scrupulous and rigorous research of the literature and can be the starting point for monitoring the knowledge on this topic in the coming years. This study is the first to analyze the knowledge and management of pathology by PTs with different specializations and not only hand rehabilitation experts as has happened up to now. This survey is also the first study undertaken not only in the Italian context, but also in the European context, and thus could be the starting point for studies in/of other nations.

\section{Conclusions}

Most respondents are aware of the nosological characteristics, major risk factors, diagnostic tests, and specific outcome measures of CTS. The management of the disease was not always, and not completely, in line with current evidence. The survey showed greater adherence on the part of PTs holding a Master's degree. Interventions such as education, manual therapy, and therapeutic exercise, as well as the nerve glide and tendon techniques are widely used, while the orthotic is only offered by half of the sample.

Author Contributions: Conceptualization, V.S., F.B. (Fabrizio Brindisino), S.M. and F.B. (Francesca Bonetti); methodology, F.B. (Fabrizio Brindisino) and F.B. (Francesca Bonetti); investigation, F.B. (Fabrizio Brindisino), S.M. and F.B. (Francesca Bonetti); project administration, V.S. and S.M.; statistics, L.P.; writing, V.S., F.B. (Fabrizio Brindisino) and S.M.; reviewing and editing, L.P. and F.B. (Francesca Bonetti); supervision, F.B. (Francesca Bonetti). All authors have read and agreed to the published version of the manuscript.

Funding: L.P. was (partially) supported by funding of the Italian Ministry of Health (ricerca corrente).

Institutional Review Board Statement: The study was conducted according to the guidelines of the Declaration of Helsinki, and approved by the Ethics Committee of ethics committee of Lecce, Italy (Minutes No. 40 of 10 December 2019).

Informed Consent Statement: Informed consent was obtained from all subjects involved in the study.

Data Availability Statement: The data presented in this study are available on request from the corresponding author.

Acknowledgments: The authors are grateful to Brett Merritt for his precious linguistic advice during the advancement of this manuscript. The authors would also like to thank all the Italian physiotherapists who took part in the survey.

Conflicts of Interest: The authors declare no conflict of interest.

\section{Appendix A}

1. Age:

- $\quad<29$ years

- $\quad 30-39$ years

- $40-49$ years 
- $\quad>50$ years

2. Gender:

- Male

- Female

3. Years of clinical practice:

- $\quad<5$ years

- 5-10 years

- 11-20 years

- $>20$ years

4. Current academic degree (select the highest degree):

- Bachelor's degree in Physiotherapy

- First level university master degree

- Master of science degree in Rehabilitation Sciences of Health Professions

- PhD degree

5. Workplace:

- Hospital

- Private practice

- Rehabilitation Center specialized in hand and wrist rehabilitation

- Sports club, association or federation

- University (teaching or research activity)

6. Field of work:

- Musculoskeletal

- Geriatric

- Neurological

- Other

7. Italian Region:

- North

- South

- Center

8. Patients with Carpal Tunnel Syndrome/year:

- $1-5$

- 6-10

- $11-15$

- 15

9. Carpal Tunnel Syndrome: what is it?

- A neurological condition caused by compression of the median nerve due to an increase in pressure within the carpal tunnel

- A neurological condition caused by compression of the ulnar nerve due to an increase in pressure within the carpal tunnel

- A pathology that affects the flexor tendons of the fingers in the passage within the carpal tunnel due to functional overload

- A pathology affecting the median nerve due to an increase in pressure within the Guyon canal

10. Which of these causes do you think is the most likely for developing Carpal Tunnel Syndrome?

- Collagen alteration

- Reduction of space within the Guyon canal

- Reduction of space within the carpal canal

- Presence of a scaphoid osteophyte 
11. Do you think that a patient with Carpal Tunnel Syndrome is the responsibility of the physical therapist?

- Yes

- No

- Yes, but only in the case of preventive median nerve conduction studies (electro myography-EMG)

- Yes, but only in the case of a preventive specialist medical examination

12. Which risk factors seem to be most associated with Carpal Tunnel Syndrome?

- Female gender, obesity, diabetes and pregnancy

- Age $(<70)$, male gender and diabetes

- Alcohol, smoking and hormonal pathologies

- Diabetes, male gender, age $(>60)$

13. Do you agree that there is an association between Carpal Tunnel Syndrome and computer use?

- Yes

- No

- Only when exceeding $10 \mathrm{~h}$ per day

- If it is accompanied with the use of a non-ergonomic mouse

14. What signs and symptoms can characterize Carpal Tunnel Syndrome?

- Alteration of the sensitivity of the palm, in particular of the thenar eminence

- Altered sensitivity, tingling and numbness of the first three fingers

- Joint limitation of the radiocarpal joint

- Strength deficit of the muscles of the hypothenar eminence

15. During the physical examination it is possible to find:

- Hypotrophy of the dorsal and palmar aspect of the hand, including thenar and hypothenar eminence

- Hypotrophy of the hypothenar eminence

- Hypotrophy of the thenar eminence

- Oedema localized to the distal joints

16. Best tools for the examination of tactile sensitivity:

- A pin

- The Semmes-Weinstein Monofilament

- There is no appropriate tool

- The description of the patient is sufficient

17. Which clinical tests would you use most frequently during the evaluation of a patient with probable Carpal Tunnel Syndrome?

- Wrist flexion test (Phalen's test), nerve percussion test (Tinel's sign), Functional Dexterity test and two-point discrimination

- Phalen's maneuver, Upper Limb Neurodynamic Test 3 (ULNT-3 for ulnar nerve), two-point discrimination test

- $\quad$ Resisted wrist extension test (Cozen's test), sensitivity evaluation in the thenar eminence and in the palmar aspect of the hand

- Phalen's maneuver, Upper Limb Neurodynamic Test 1 (ULNT-1 for median nerve) and test for stability between the scaphoid and other carpal bones (Watson's Test)

18. What outcome measures would you use to evaluate the patient with Carpal Tunnel Syndrome?

- Administration of a pain scale, such as the Visual Analog Scale (VAS) or the Numeric Pain Rating Scale (NPRS)

- Measurement of strength with dynamometer and manual dexterity 
- Measurement of strength with dynamometer and of sensitivity, manual dexterity, strength and pain and administration of a questionnaire for the evaluation of symptoms and function

- Interview with the patient

19. Would you advice-or directly build-an orthotic for the management of patients with Carpal Tunnel Syndrome?

- Yes

- No

- No, it's contraindicated

- Yes, but only if the disorder is accompanied by rhizarthrosis

20. How is the evidence supporting the use of instrumental therapies in the management of patients with Carpal Tunnel Syndrome?

- Weak/moderate, but I still use them in my clinical practice

- Weak/moderate; I don't use instrumental therapies in my clinical practice

- Strong, therefore I use them in my clinical practice

- Strong, but I don't use them in my clinical practice

21. Do you think that the neural mobilization techniques (neurodynamic) and tendon gliding exercises are supported by evidence in literature?

- Yes, there is strong evidence and that's why I use these techniques in my clinical practice

- Yes, there is strong evidence but I don't use these techniques in my clinical practice

- No, there is limited evidence and that's why I don't use these techniques in my clinical practice

- There is limited evidence, but I still use these techniques in my clinical practice

22. Which treatment strategy would you use most frequently for the management of patients with Carpal Tunnel Syndrome?

- Massage therapy, instrumental therapy

- Education, manual therapy, myofascial therapy, therapeutic exercise

- Joint mobilization of the radiocarpal joint, stretching

- None of the previous answers

23. Do you think that psychosocial factors involving the processes of central sensitization can influence outcomes of patients with Carpal Tunnel Syndrome?

- Yes, and I adapt my clinical practice accordingly

- Yes, but I don't know how to adapt my clinical practice

- No, psychosocial factors do not influence the outcomes of these patients

- Yes, and my clinical practice is only aimed at the education and explanation of these processes

24. Do you think that the surgical approach can be the solution for patients with Carpal Tunnel Syndrome?

- Never

- Yes, in cases of failure of conservative treatment (persistence of symptoms)

- Yes, always

- Yes, in the presence of stenosing tenosynovitis 


\section{Appendix B}

Table A1. Analytic responses.

\begin{tabular}{|c|c|c|c|c|}
\hline Question & Possible Choices & Frequency & Percentage & Missing \\
\hline \multirow{4}{*}{$\begin{array}{l}\text { Q:9 } \\
\text { Carpal Tunnel Syndrome: } \\
\text { what is it? }\end{array}$} & $\begin{array}{l}\text { A neurological condition caused by compression of the median } \\
\text { nerve due to an increase in pressure within the carpal tunnel }\end{array}$ & 469 & 92.3 & \multirow{4}{*}{0} \\
\hline & $\begin{array}{l}\text { A neurological condition caused by compression of the ulnar } \\
\text { nerve due to an increase in pressure within the carpal tunnel }\end{array}$ & 5 & 0.98 & \\
\hline & $\begin{array}{l}\text { A pathology that affects the flexor tendons of the fingers in the } \\
\text { passage within the carpal tunnel due to functional overload }\end{array}$ & 16 & 3.15 & \\
\hline & $\begin{array}{l}\text { A pathology affecting the median nerve due to an increase in } \\
\text { pressure within the Guyon canal }\end{array}$ & 18 & 3.54 & \\
\hline \multirow{4}{*}{$\begin{array}{l}\text { Q:10 } \\
\text { Which of these causes do } \\
\text { you think is the most } \\
\text { likely for developing } \\
\text { Carpal Tunnel Syndrome? }\end{array}$} & Collagen alteration & 13 & 2.56 & \multirow{4}{*}{1} \\
\hline & Reduction of space within the Guyon canal & 37 & 7.28 & \\
\hline & Reduction of space within the carpal canal & 455 & 89.6 & \\
\hline & Presence of a scaphoid osteophyte & 2 & 0.39 & \\
\hline \multirow{4}{*}{$\begin{array}{l}\text { Q:11 } \\
\text { Do you think that a } \\
\text { patient with Carpal } \\
\text { Tunnel Syndrome is the } \\
\text { responsibility of the } \\
\text { physical therapist? }\end{array}$} & Yes & 360 & 70.9 & \multirow{4}{*}{0} \\
\hline & No & 4 & 0.80 & \\
\hline & $\begin{array}{c}\text { Yes, but only in the case of preventive median nerve conduction } \\
\text { studies (electromyography-EMG) }\end{array}$ & 66 & 12.99 & \\
\hline & $\begin{array}{l}\text { Yes, but only in the case of a preventive specialist } \\
\text { medical examination }\end{array}$ & 78 & 15.35 & \\
\hline \multirow{4}{*}{$\begin{array}{l}\text { Q:12 } \\
\text { Which risk factors seem to } \\
\text { be most associated with } \\
\text { Carpal Tunnel Syndrome? }\end{array}$} & Female gender, obesity, diabetes and pregnancy & 448 & 88.20 & \multirow{4}{*}{1} \\
\hline & Age $(<70)$, male gender and diabetes & 14 & 2.75 & \\
\hline & Alcohol, smoking and hormonal pathologies & 26 & 5.12 & \\
\hline & Diabetes, male gender, age $(>60)$ & 20 & 3.94 & \\
\hline \multirow{4}{*}{$\begin{array}{l}\text { Q:13 } \\
\text { Do you agree that there is } \\
\text { an association between } \\
\text { Carpal Tunnel Syndrome } \\
\text { and computer use? }\end{array}$} & Yes & 298 & 58.70 & \multirow{4}{*}{1} \\
\hline & No & 89 & 17.50 & \\
\hline & Only when exceeding 10 hours per day & 83 & 16.30 & \\
\hline & If it is accompanied with the use of a non-ergonomic mouse & 37 & 7.30 & \\
\hline \multirow{4}{*}{$\begin{array}{c}\text { Q:14 } \\
\text { What signs and symptoms } \\
\text { can characterize Carpal } \\
\text { Tunnel Syndrome? }\end{array}$} & $\begin{array}{c}\text { Alteration of the sensitivity of the palm, in particular of the } \\
\text { thenar eminence }\end{array}$ & 80 & 15.70 & \multirow{4}{*}{0} \\
\hline & $\begin{array}{l}\text { Altered sensitivity, tingling and numbness of the first } \\
\text { three fingers }\end{array}$ & 415 & 81.70 & \\
\hline & Joint limitation of the radiocarpal joint & 5 & 0.98 & \\
\hline & Strength deficit of the muscles of the hypothenar eminence & 8 & 1.57 & \\
\hline \multirow{4}{*}{$\begin{array}{l}\text { Q:15 } \\
\text { During the physical } \\
\text { examination it is possible } \\
\text { to find? }\end{array}$} & $\begin{array}{l}\text { Hypotrophy of the dorsal and palmar aspect of the hand, } \\
\text { including thenar and hypothenar eminence }\end{array}$ & 81 & 15.95 & \multirow{4}{*}{2} \\
\hline & Hypotrophy of the hypothenar eminence & 31 & 6.10 & \\
\hline & Hypotrophy of the thenar eminence & 380 & 74.80 & \\
\hline & Oedema localized to the distal joints & 14 & 2.75 & \\
\hline \multirow{4}{*}{$\begin{array}{l}\text { Q:16 } \\
\text { Best tools for the } \\
\text { examination of tactile } \\
\text { sensitivity? }\end{array}$} & A pin & 90 & 17.70 & \multirow{4}{*}{5} \\
\hline & The Semmes-Weinstein Monofilament & 264 & 52.00 & \\
\hline & There is no appropriate tool & 76 & 15.00 & \\
\hline & The description of the patient is sufficient & 73 & 14.40 & \\
\hline
\end{tabular}


Table A1. Cont.

\begin{tabular}{|c|c|c|c|c|}
\hline Question & Possible Choices & Frequency & Percentage & Missing \\
\hline \multirow{4}{*}{$\begin{array}{l}\text { Q:17 } \\
\text { Which clinical tests would } \\
\text { you use most frequently } \\
\text { during the evaluation of a } \\
\text { patient with probable } \\
\text { Carpal Tunnel Syndrome? }\end{array}$} & $\begin{array}{l}\text { Wrist flexion test (Phalen's maneuver), nerve percussion test } \\
\text { (Tinel's sign), Functional Dexterity test and two-point } \\
\text { discrimination }\end{array}$ & 341 & 67.12 & \multirow{4}{*}{8} \\
\hline & $\begin{array}{c}\text { Phalen's maneuver, Upper Limb Neurodynamic Test } 3 \text { (ULNT-3 } \\
\text { for ulnar nerve), two-point discrimination test }\end{array}$ & 33 & 6.48 & \\
\hline & $\begin{array}{l}\text { Resisted wrist extension test (Cozen's test), sensitivity } \\
\text { evaluation in the thenar eminence and in the palmar aspect of } \\
\text { the hand }\end{array}$ & 35 & 6.89 & \\
\hline & $\begin{array}{c}\text { Phalen's maneuver, Upper Limb Neurodynamic Test } 1 \text { (ULNT-1 } \\
\text { for median nerve) and test for stability between the scaphoid } \\
\text { and other carpal bones (Watson's Test) }\end{array}$ & 91 & 17.91 & \\
\hline \multirow{4}{*}{$\begin{array}{l}\text { Q:18 } \\
\text { What outcome measures } \\
\text { would you use to evaluate } \\
\text { the patient with Carpal } \\
\text { Tunnel Syndrome? }\end{array}$} & $\begin{array}{l}\text { Administration of a pain scale, such as the Visual Analog Scale } \\
\text { (VAS) or the Numeric Pain Rating Scale (NPRS) }\end{array}$ & 42 & 8.27 & \multirow{4}{*}{3} \\
\hline & $\begin{array}{l}\text { Measurement of strength with dynamometer and } \\
\text { manual dexterity }\end{array}$ & 8 & 1.57 & \\
\hline & $\begin{array}{l}\text { Measurement of strength with dynamometer and of sensitivity, } \\
\text { manual dexterity, strength and pain and administration of a } \\
\text { questionnaire for the evaluation of symptoms and function }\end{array}$ & 423 & 83.27 & \\
\hline & Interview with the patients & 32 & 6.28 & \\
\hline \multirow{4}{*}{$\begin{array}{c}\text { Q:19 } \\
\text { Would you advice-or } \\
\text { directly build-an orthotic } \\
\text { for the management of } \\
\text { patients with Carpal } \\
\text { Tunnel Syndrome? }\end{array}$} & Yes & 269 & 52.95 & \multirow{4}{*}{2} \\
\hline & No & 163 & 32.28 & \\
\hline & No, it's contraindicated & 12 & 2.46 & \\
\hline & Yes, but only if the disorder is accompanied by rhizarthrosis & 62 & 12.30 & \\
\hline \multirow{4}{*}{$\begin{array}{c}\text { Q:20 } \\
\text { How is the evidence } \\
\text { supporting the use of } \\
\text { instrumental modalities in } \\
\text { the management of } \\
\text { patients with Carpal } \\
\text { Tunnel Syndrome? }\end{array}$} & Weak/moderate, but I still use them in my clinical practice & 194 & 38.20 & \multirow{4}{*}{5} \\
\hline & $\begin{array}{c}\text { Weak/moderate; I don't use instrumental therapies in my } \\
\text { clinical practice }\end{array}$ & 285 & 56.10 & \\
\hline & Strong, therefore I use them in my clinical practice & 19 & 3.73 & \\
\hline & Strong, but I don't use them in my clinical practice & 5 & 0.98 & \\
\hline \multirow{4}{*}{$\begin{array}{c}\text { Q:21 } \\
\text { Do you think that the } \\
\text { neural mobilization } \\
\text { techniques } \\
\text { (neurodynamic) and } \\
\text { tendon gliding exercises } \\
\text { are supported by evidence } \\
\text { in literature? }\end{array}$} & $\begin{array}{l}\text { Yes, there is strong evidence and that's why I use these } \\
\text { techniques in my clinical practice }\end{array}$ & 175 & 34.40 & \multirow{4}{*}{9} \\
\hline & $\begin{array}{l}\text { Yes, there is strong evidence but I don't use these techniques in } \\
\text { my clinical practice }\end{array}$ & 38 & 7.51 & \\
\hline & $\begin{array}{l}\text { No, there is limited evidence and that's why I don't use these } \\
\text { techniques in my clinical practice }\end{array}$ & 38 & 7.51 & \\
\hline & $\begin{array}{c}\text { There is limited evidence, but I still use these techniques in my } \\
\text { clinical practice }\end{array}$ & 251 & 49.40 & \\
\hline \multirow{4}{*}{$\begin{array}{c}\text { Q:22 } \\
\text { Which treatment strategy } \\
\text { would you use most } \\
\text { frequently for the } \\
\text { management of patients } \\
\text { with Carpal Tunnel } \\
\text { Syndrome? }\end{array}$} & Massage therapy, instrumental therapy & 21 & 4.13 & \multirow{4}{*}{1} \\
\hline & $\begin{array}{l}\text { Education, manual therapy, myofascial therapy, } \\
\text { therapeutic exercise }\end{array}$ & 457 & 89.88 & \\
\hline & Joint mobilization of the radiocarpal joint, stretching & 7 & 1.38 & \\
\hline & None of the previous answers & 22 & 4.33 & \\
\hline \multirow{4}{*}{$\begin{array}{c}\text { Q:23 } \\
\text { Do you think that } \\
\text { psychosocial factors } \\
\text { involving the processes of } \\
\text { central sensitization can } \\
\text { influence outcomes of } \\
\text { patients with Carpal } \\
\text { Tunnel Syndrome? }\end{array}$} & Yes, and I adapt my clinical practice accordingly & 364 & 71.68 & \multirow{4}{*}{2} \\
\hline & Yes, but I don't know how to adapt my clinical practice & 83 & 16.34 & \\
\hline & $\begin{array}{l}\text { No, psychosocial factors do not influence the outcomes of } \\
\text { these patients }\end{array}$ & 23 & 4.48 & \\
\hline & $\begin{array}{l}\text { Yes, and my clinical practice is only aimed at the education and } \\
\text { explanation of these processes }\end{array}$ & 36 & 7.09 & \\
\hline \multirow{4}{*}{$\begin{array}{l}\text { Q:24 } \\
\text { Do you think that the } \\
\text { surgical approach can be } \\
\text { the solution for patients } \\
\text { with Carpal Tunnel } \\
\text { Syndrome? }\end{array}$} & Never & 12 & 2.36 & \multirow{4}{*}{1} \\
\hline & $\begin{array}{l}\text { Yes, in cases of failure of conservative treatment } \\
\text { (persistence of symptoms) }\end{array}$ & 468 & 92.08 & \\
\hline & Yes, always & 6 & 1.18 & \\
\hline & Yes, in the presence of stenosing tenosynovitis & 21 & 4.13 & \\
\hline
\end{tabular}




\section{References}

1. Lawrence, R.C.; Felson, D.T.; Helmick, C.G.; Arnold, L.M.; Choi, H.; Deyo, R.A.; Gabriel, S.; Hirsch, R.; Hochberg, M.C.; Hunder, G.G.; et al. Estimates of the prevalence of arthritis and other rheumatic conditions in the United States: Part II. Arthritis Rheum. 2007, 58, 26-35. [CrossRef]

2. Dale, A.M.; Harris-Adamson, C.; Rempel, D.; Gerr, F.; Hegmann, K.; Silverstein, B.; Burt, S.; Garg, A.; Kapellusch, J.; Merlino, L.; et al. Prevalence and incidence of carpal tunnel syndrome in US working populations: Pooled analysis of six prospective studies. Scand. J. Work. Environ. Health 2013, 39, 495-505. [CrossRef]

3. ANMIL. Musculoskeletal and Biomechanical Overload Disorders of Workers in the Commercial Sector: A Comparative Picture. 2013. Available online: http:/ / www.ctr.it/back_end/files_news/1577.pdf (accessed on 10 January 2021).

4. INAIL. Accidents and Occupational Diseases, Inail Open Data for the First Five Months of 2019-2020 Are Online. 2020. Available online: https:/ / www.inail.it/cs/internet/comunicazione/sala-stampa/comunicati-stampa/com-stampa-open-data-maggio2020.html (accessed on 10 January 2021).

5. Spector, J.T.; Turner, J.A.; Fulton-Kehoe, D.; Franklin, G. Pre-surgery disability compensation predicts long-term disability among workers with carpal tunnel syndrome. Am. J. Ind. Med. 2012, 55, 816-832. [CrossRef]

6. Nuckols, T.; Conlon, C.; Robbins, M.; Dworsky, M.; Lai, J.; Roth, C.P.; Levitan, B.; Seabury, S.; Seelam, R.; Asch, S.M. Quality of care for work-associated carpal tunnel syndrome. J. Occup. Environ. Med. 2017, 59, 47-53. [CrossRef]

7. Wright, C.; Smith, B.; Wright, S.; Weiner, M.; Wright, K.; Rubin, D. Who develops carpal tunnel syndrome during pregnancy: An analysis of obesity, gestational weight gain, and parity. Obstet. Med. 2014, 7, 90-94. [CrossRef]

8. Shiri, R.; Pourmemari, M.H.; Falahhassani, K.; Viikarijuntura, E. The effect of excess body mass on the risk of carpal tunnel syndrome: A meta-analysis of 58 studies. Obes. Rev. 2015, 16, 1094-1104. [CrossRef]

9. Harris-Adamson, C.; Eisen, A.E.; Dale, A.M.; Evanoff, B.; Hegmann, K.T.; Thiese, M.S.; Kapellusch, J.M.; Garg, A.; Burt, S.; Bao, S.; et al. Personal and workplace psychosocial risk factors for carpal tunnel syndrome: A pooled study cohort. Occup. Environ. Med. 2013, 70, 529-537. [CrossRef] [PubMed]

10. Harris-Adamson, C.; Eisen, A.E.; Kapellusch, J.; Garg, A.; Hegmann, K.T.; Thiese, M.S.; Dale, A.M.; Evanoff, B.; Burt, S.; Bao, S.; et al. Biomechanical risk factors for carpal tunnel syndrome: A pooled study of 2474 workers. Occup. Environ. Med. 2014, 72, 33-41. [CrossRef]

11. Harris-Adamson, C.; Eisen, A.E.; Neophytou, A.; Kapellusch, J.; Garg, A.; Hegmann, K.T.; Thiese, M.S.; Dale, A.M.; Evanoff, B.; Bao, S.; et al. Biomechanical and psychosocial exposures are independent risk factors for carpal tunnel syndrome: Assessment of confounding using causal diagrams. Occup. Environ. Med. 2016, 73, 727-734. [CrossRef] [PubMed]

12. Al-Hashem, F.H.; Khalid, M.-E.M. The effect of long-term use of computer mouse devices on median nerve entrapment. Neuroscience 2008, 13, 131-135.

13. Andersen, J.H.; Fallentin, N.; Thomsen, J.F.; Mikkelsen, S. Risk factors for neck and upper extremity disorders among computers users and the effect of interventions: An overview of systematic reviews. PLoS ONE 2011, 6, e19691. [CrossRef]

14. Mediouni, Z.; Bodin, J.; Dale, A.M.; Herquelot, E.; Carton, M.; Leclerc, A.; Fouquet, N.; Dumontier, C.; Roquelaure, Y.; Evanoff, B.; et al. Carpal tunnel syndrome and computer exposure at work in two large complementary cohorts. BMJ Open 2015, 5, e008156. [CrossRef]

15. Petit, A.; Ha, C.; Bodin, J.; Rigouin, P.; Descatha, A.; Brunet, R.; Goldberg, M.; Roquelaure, Y. Risk factors for carpal tunnel syndrome related to the work organization: A prospective surveillance study in a large working population. Appl. Ergon. 2015, 47, 1-10. [CrossRef]

16. Rempel, D.M.; Keir, P.J.; Bach, J.M. Effect of wrist posture on carpal tunnel pressure while typing. J. Orthop. Res. 2008, 26, 1269-1273. [CrossRef] [PubMed]

17. Calandruccio, J.H.; Thompson, N.B. Carpal tunnel syndrome. Orthop. Clin. N. Am. 2018, 49, 223-229. [CrossRef]

18. Kozak, A.; Schedlbauer, G.; Wirth, T.; Euler, U.; Westermann, C.; Nienhaus, A. Association between work-related biomechanical risk factors and the occurrence of carpal tunnel syndrome: An overview of systematic reviews and a meta-analysis of current research. BMC Musculoskelet. Disord. 2015, 16, 231. [CrossRef]

19. Mattioli, S.; Violante, F.S.; Bonfiglioli, R. Upper-extremity and neck disorders associated with keyboard and mouse use. Handb. Clin. Neurol. 2015, 131, 427-433. [CrossRef]

20. Coenen, P.; Van Der Molen, H.F.; Burdorf, A.; Huysmans, M.; Straker, L.; Frings-Dresen, M.H.; Van Der Beek, A.J. Associations of screen work with neck and upper extremity symptoms: A systematic review with meta-analysis. Occup. Environ. Med. 2019, 76, 502-509. [CrossRef]

21. Giannini, F.; Cioni, R.; Mondelli, M.; Padua, R.; Gregori, B.; D'Amico, P.; Padua, L. A new clinical scale of carpal tunnel syndrome: Validation of the measurement and clinical-neurophysiological assessment. Clin. Neurophysiol. 2002, 113, 71-77. [CrossRef]

22. Wang, W.L.; Buterbaugh, K.; Kadow, T.R.; Goitz, R.J.; Fowler, J.R. A prospective comparison of diagnostic tools for the diagnosis of carpal tunnel syndrome. J. Hand Surg. 2018, 43, 833-836.e2. [CrossRef]

23. de-la-Llave-Rincon, A.I.; Puentedura, E.J.; Fernandez-de-las-Penas, C. New advances in the mechanisms and etiology of carpal tunnel syndrome. Discov. Med. 2012, 13, 343-348. 
24. Fernández-De-Las-Peñas, C.; De-La-Llave-Rincón, A.I.; Cescon, C.; Barbero, M.; Arias-Buría, J.L.; Falla, D. Influence of clinical, psychological, and psychophysical variables on long-term treatment outcomes in carpal tunnel syndrome: Evidence from a randomized clinical trial. Pain Pract. 2019, 19, 644-655. [CrossRef]

25. Fernández-De-Las-Peñas, C.; Fernández-Muñoz, J.J.; Navarro-Pardo, E.; Da-Silva-Pocinho, R.F.; Ambite-Quesada, S.; Pareja, J.A. Identification of subgroups of women with carpal tunnel syndrome with central sensitization. Pain Med. 2016, 17, $1749-1756$. [CrossRef]

26. Soon, B.; Vicenzino, B.; Schmid, A.B.; Coppieters, M.W. Facilitatory and inhibitory pain mechanisms are altered in patients with carpal tunnel syndrome. PLoS ONE 2017, 12, e0183252. [CrossRef]

27. Sartorio, F.; Vercelli, S.; Bravini, E.; Zanetta, A.; Bargeri, S.; Pisano, F.; Ferriero, G. Assessment of dexterity and diagnostic accuracy of the Functional Dexterity Test in patients with carpal tunnel syndrome. La Med. Lav. 2018, 109, 31-39.

28. D'Arcy, C.A.; McGee, S. Does this Patient have carpal tunnel syndrome? JAMA 2000, 283, 3110. [CrossRef]

29. Trillos, M.-C.; Soto, F.; Briceno-Ayala, L. Upper limb neurodynamic test 1 in patients with clinical diagnosis of carpal tunnel syndrome: A diagnostic accuracy study. J. Hand Ther. 2018, 31, 333-338. [CrossRef]

30. Erickson, M.; Lawrence, M.; Jansen, C.W.S.; Coker, D.; Amadio, P.; Cleary, C. Hand pain and sensory deficits: Carpal tunnel syndrome. J. Orthop. Sports Phys. Ther. 2019, 49, CPG1-CPG85. [CrossRef]

31. Huisstede, B.M.; Fridén, J.; Coert, J.H.; Hoogvliet, P. Carpal tunnel syndrome: Hand surgeons, hand therapists, and physical medicine and rehabilitation physicians agree on a multidisciplinary treatment guideline-Results from the European Handguide Study. Arch. Phys. Med. Rehabil. 2014, 95, 2253-2263. [CrossRef]

32. Ma, H.; Kim, I. The diagnostic assessment of hand elevation test in carpal tunnel syndrome. J. Korean Neurosurg. Soc. 2012, 52, 472-475. [CrossRef] [PubMed]

33. Durham, C.O.; VanRavenstein, K. It's all in the wrist. Orthop. Nurs. 2017, 36, 323-327. [CrossRef]

34. Burton, C.L.; Chesterton, L.S.; Chen, Y.; Van Der Windt, D.A. Clinical course and prognostic factors in conservatively managed carpal tunnel syndrome: A systematic review. Arch. Phys. Med. Rehabil. 2016, 97, 836-852.e1. [CrossRef]

35. 741/94 L. Professional Profile of the Italian Physiotherapist. Gazzetta Ufficiale. 9 January 1995. Available online: http: //www.salute.gov.it/imgs/C_17_normativa_1867_allegato.pdf (accessed on 10 January 2021).

36. Alfonso, C.; Jann, S.; Massa, R.; Torreggiani, A. Diagnosis, treatment and follow-up of the carpal tunnel syndrome: A review. Neurol. Sci. 2010, 31, 243-252. [CrossRef]

37. Villafañe, J.H.; Valdes, K.; O’Brien, V.; Seves, M.; Cantero-Téllez, R.; Berjano, P. Conservative management of thumb carpometacarpal osteoarthritis: An Italian survey of current clinical practice. J. Bodyw. Mov. Ther. 2018, 22, 37-39. [CrossRef]

38. Stephens, G.; O'Neill, S.; French, H.P.; Fearon, A.; Grimaldi, A.; O'Connor, L.; Woodley, S.; Littlewood, C. A survey of physiotherapy practice (2018) in the United Kingdom for patients with greater trochanteric pain syndrome. Musculoskelet. Sci. Pract. 2019, 40, 10-20. [CrossRef]

39. Grieve, R.; Palmer, S. Physiotherapy for plantar fasciitis: A UK-wide survey of current practice. Physiotherapy 2017, 103, 193-200. [CrossRef]

40. MacDermid, J.C.; Wojkowski, S.; Kargus, C.; Marley, M.; Stevenson, E. Hand therapist management of the lateral epicondylosis: A survey of expert opinion and practice patterns. J. Hand Ther. 2010, 23, 18-30. [CrossRef]

41. Cantero-Tellez, R.; Valdes, K.; Garcia-Orza, S.; Villafane, J. Current practice patterns after carpal tunnel release. A survey of clinical practice trends across the world. Mathews J. Orthop. 2018, 3, 019.

42. Von Elm, E.; Altman, D.G.; Egger, M.; Pocock, S.J.; Gøtzsche, P.C.; Vandenbroucke, J.P. The strengthening the reporting of observational studies in epidemiology (STROBE) statement: Guidelines for reporting observational studies. J. Clin. Epidemiol. 2008, 61, 344-349. [CrossRef]

43. Eysenbach, G. Improving the quality of Web surveys: The Checklist for reporting results of internet E-Surveys (CHERRIES). J. Med. Internet Res. 2004, 6, e34. [CrossRef]

44. Bury, J.; Littlewood, C. Rotator cuff disorders: A survey of current (2016) UK physiotherapy practice. Shoulder Elb. 2017, 10, 52-61. [CrossRef]

45. Pieters, L.; Voogt, L.; Bury, J.; Littlewood, C.; Feijen, S.; Cavaggion, C.; Struyf, F. Rotator CUFF disorders: A survey of current physiotherapy practice in Belgium and the Netherlands. Musculoskelet. Sci. Pract. 2019, 43, 45-51. [CrossRef]

46. Brindisino, F.; Matteuzzi, I.; Bury, J.; McCreesh, K.; Littlewood, C. Rotator cuff disorders: A survey of current (2018) Italian physiotherapy practice. Physiother. Pract. Res. 2020, 41, 11-22. [CrossRef]

47. Fan, W.; Yan, Z. Factors affecting response rates of the web survey: A systematic review. Comput. Hum. Behav. 2010, 26, 132-139. [CrossRef]

48. Regmi, P.R.; Waithaka, E.; Paudyal, A.; Simkhada, P.; Van Teijlingen, E. Guide to the design and application of online questionnaire surveys. Nepal J. Epidemiol. 2017, 6, 640-644. [CrossRef]

49. Rossettini, G.; Palese, A.; Geri, T.; Fiorio, M.; Colloca, L.; Testa, M. Physical therapists' perspectives on using contextual factors in clinical practice: Findings from an Italian national survey. PLoS ONE 2018, 13, e0208159. [CrossRef]

50. Haberman, S.J. The analysis of residuals in cross-classified tables. Biometrics 1973, 29, 205. [CrossRef]

51. Beasley, T.M.; Schumacker, R.E. Multiple regression approach to analyzing contingency tables: Post hoc and planned comparison procedures. J. Exp. Educ. 1995, 64, 79-93. [CrossRef] 
52. García-Pérez, M.A.; Núñez-Antón, V. Cellwise residual analysis in two-way contingency tables. Educ. Psychol. Meas. 2003, 63, 825-839. [CrossRef]

53. Graham, B.; Peljovich, A.E.; Rempel, D.; Rozental, T.D.; Salajegheh, M.K.; Keith, M.W.; Jevsevar, D.S.; Shea, K.G.; Bozic, K.J.; Adams, J.; et al. The American academy of orthopaedic surgeons evidence-based clinical practice guideline on. J. Bone Jt. Surg. 2016, 98, 1750-1754. [CrossRef]

54. Carpal tunnel syndrome: A summary of clinical practice guideline recommendations-Using the evidence to guide physical therapist practice. J. Orthop. Sports Phys. Ther. 2019, 49, 359-360. [CrossRef] [PubMed]

55. Peñas, C.F.-D.-L.; Ortega-Santiago, R.; De La Llave-Rincón, A.I.; Martínez-Perez, A.; Díaz, H.F.-S.; Martínez-Martín, J.; Pareja, J.A.; Cuadrado-Pérez, M.L. Manual physical therapy versus surgery for carpal tunnel syndrome: A randomized parallel-group trial. $J$. Pain 2015, 16, 1087-1094. [CrossRef]

56. Shi, Q.; Bobos, P.; Lalone, E.A.; Warren, L.; MacDermid, J.C. Comparison of the short-term and long-term effects of surgery and nonsurgical intervention in treating carpal tunnel syndrome: A systematic review and meta-analysis. HAND 2018, 15, 13-22. [CrossRef]

57. Rahman Shiri, K.F.-H. Computer use and carpal tunnel syndrome: A meta-analysis. J. Neurol. Sci. 2015, 15, 15-19. [CrossRef]

58. Mediouni, Z.; De Roquemaurel, A.; Dumontier, C.; Becour, B.; Garrabe, H.; Roquelaure, Y.; Descatha, A. Is carpal tunnel syndrome related to computer exposure at work? A review and meta-analysis. J. Occup. Environ. Med. 2014, 56, 204-208. [CrossRef] [PubMed]

59. Wipperman, J.; Goerl, K. Carpal tunnel syndrome: Diagnosis and management. Am. Fam. Physician 2016, 94, 993-999.

60. Burton, C.; Chesterton, L.S.; Davenport, G. Diagnosing and managing carpal tunnel syndrome in primary care. Br. J. Gen. Pract. 2014, 64, 262-263. [CrossRef]

61. Padua, L.; Coraci, D.; Erra, C.; Pazzaglia, C.; Paolasso, I.; Loreti, C.; Caliandro, P.; Hobson-Webb, L.D. Carpal tunnel syndrome: Clinical features, diagnosis, and management. Lancet Neurol. 2016, 15, 1273-1284. [CrossRef]

62. Ballestero-Pérez, R.; Plaza-Manzano, G.; Urraca-Gesto, A.; Romo-Romo, F.; Atín-Arratibel, M.D.L.Á.; Pecos-Martín, D.; GallegoIzquierdo, T.; Romero-Franco, N. Effectiveness of nerve gliding exercises on carpal tunnel syndrome: A systematic review. J. Manip. Physiol. Ther. 2017, 40, 50-59. [CrossRef]

63. Kim, S.-D. Efficacy of tendon and nerve gliding exercises for carpal tunnel syndrome: A systematic review of randomized controlled trials. J. Phys. Ther. Sci. 2015, 27, 2645-2648. [CrossRef]

64. Page, M.J.; O'Connor, D.; Pitt, V.; Massy-Westropp, N. Exercise and mobilisation interventions for carpal tunnel syndrome. Cochrane Database Syst. Rev. 2012, 6, CD009899. [CrossRef]

65. Huisstede, B.M.; Hoogvliet, P.; Franke, T.P.; Randsdorp, M.S.; Koes, B.W. Carpal tunnel syndrome: Effectiveness of physical therapy and electrophysical modalities. An updated systematic review of randomized controlled trials. Arch. Phys. Med. Rehabil. 2018, 99, 1623-1634.e23. [CrossRef]

66. Nunez, F.; Vranceanu, A.-M.; Ring, D. Determinants of pain in patients with carpal tunnel syndrome. Clin. Orthop. Relat. Res. 2010, 468, 3328-3332. [CrossRef]

67. Fernández-Muñoz, J.J.; Palacios-Ceña, M.; Cigarán-Méndez, M.; Ortega-Santiago, R.; De-La-Llave-Rincón, A.I.; Salom-Moreno, J.; Fernández-De-Las-Peñas, C. Pain is associated to clinical, psychological, physical, and neurophysiological variables in women with carpal tunnel syndrome. Clin. J. Pain 2016, 32, 122-129. [CrossRef]

68. Lehn, A.; Bullock-Saxton, J.; Newcombe, P.; Carson, A.; Stone, J. Survey of the perceptions of health practitioners regarding Functional Neurological Disorders in Australia. J. Clin. Neurosci. 2019, 67, 114-123. [CrossRef]

69. Kozakiewicz, R.T.; Bowyer, B.L. Quantitative testing and thermography in carpal tunnel syndrome. Phys. Med. Rehabil. Clin. N. Am. 1997, 8, 503-511. [CrossRef]

70. Graham, B. The value added by electrodiagnostic testing in the diagnosis of carpal tunnel syndrome. J. Bone Jt. Surg. 2008, 90, 2587-2593. [CrossRef]

71. Lee, C.-H.; Lin, Y.-T.; Wu, C.-T.; Lin, C.-H.; Chen, S.-H.; Hsu, C.-C. Sonoelastography in the diagnosis of carpal tunnel syndrome. Ann. Plast. Surg. 2021. [CrossRef]

72. Parish, R.; Morgan, C.; Burnett, C.A.; Baker, B.C.; Manning, C.; Sisson, S.K.; Shipp, E.R. Practice patterns in the conservative treatment of carpal tunnel syndrome: Survey results from members of the American Society of Hand Therapy. J. Hand Ther. 2020, 33, 346-353. [CrossRef]

73. Giovannico, G.; Brindisino, F.; Pappaccogli, M.; Saltalamacchia, A.; Bonetti, F.; Tavarnelli, M.; Mezzetti, M.; Delitto, A. A description of physical therapists knowledge in basic competence examination of musculo-skeletal conditions an Italian national cross-sectional survey. Muscle Ligaments Tendons J. 2020, 10, 686. [CrossRef]

74. Basson, A.; Olivier, B.; Ellis, R.; Coppieters, M.; Stewart, A.; Mudzi, W. The effectiveness of neural mobilization for neuromusculoskeletal conditions: A systematic review and meta-analysis. J. Orthop. Sports Phys. Ther. 2017, 47, 593-615. [CrossRef]

75. Lim, Y.H.; Chee, D.Y.; Girdler, S.; Lee, H.C. Median nerve mobilization techniques in the treatment of carpal tunnel syndrome: A systematic review. J. Hand Ther. 2017, 30, 397-406. [CrossRef] [PubMed]

76. Wolny, T. The use of neurodynamic techniques in the conservative treatment of carpal tunnel syndrome-A critical appraisal of the literature. Ortop. Traumatol. Rehabil. 2017, 19, 427-440. [CrossRef] 
77. Fernández-De-Las-Peñas, P.C.; Muñoz, J.J.F.; Palacios-Ceña, P.M.; Navarro-Pardo, E.; Ambite-Quesada, P.S.; Salom-Moreno, P.J. Direct and indirect effects of function in associated variables such as depression and severity on pain intensity in women with carpal tunnel syndrome. Pain Med. 2015, 16, 2405-2411. [CrossRef]

78. Leppänen, O.V.; Jokihaara, J.; Jämsen, E.; Karjalainen, T. Survey of hand surgeons' and therapists' perceptions of the benefit of common surgical procedures of the hand. J. Plast. Surg. Hand Surg. 2017, 52, 1-6. [CrossRef] [PubMed]

79. Jamal, A.; Temsah, M.-H.; A Khan, S.; Al-Eyadhy, A.; Koppel, C.; Chiang, M.F. Mobile phone use among medical residents: A cross-sectional multicenter survey in Saudi Arabia. JMIR mHealth uHealth 2016, 4, e61. [CrossRef] [PubMed]

80. Ball, H.L. Conducting online surveys. J. Hum. Lact. 2018, 35, 413-417. [CrossRef] [PubMed] 